\title{
Risk Factors for SARS-CoV-2 Seropositivity in a Health Care Worker Population
}

Sebastian D. Schubl MD, ${ }^{1}$ Cesar Figueroa MD,${ }^{1}$ Anton M. Palma PhD MPH, ${ }^{2}$ Rafael R. de Assis $\mathrm{PhD},{ }^{3}$ Aarti Jain MS, ${ }^{3}$ Rie Nakajima MS, ${ }^{3}$ Alguimantas Jasinkas PhD, ${ }^{3}$ Danielle Brabender MD, ${ }^{7}$ Ariana Naaseh BA, ${ }^{4}$ Oscar Hernandez Dominguez MD, ${ }^{4}$ Ava Runge MD, ${ }^{4}$ Shannon Skochko BS, ${ }^{4}$ Justine Chinn BS, ${ }^{4}$ Adam James Kelsey BS, Kieu Thai Lai BS, ${ }^{5}$ Weian Zhao PhD, ${ }^{5}$ Peter Horvath $\mathrm{PhD},{ }^{2}$ Delia Tifrea PhD, ${ }^{6}$ Areg Grigorian MD, ${ }^{7}$ Abran Gonzales BS, ${ }^{1}$ Suzanne Adelsohn MS, ${ }^{6}$ Frank Zaldivar PhD,${ }^{2}$ Robert Edwards MD PhD, ${ }^{6}$ Alpesh N. Amin MD MBA, ${ }^{9}$ Michael J. Stamos MD, ${ }^{4}$ Philip S. Barie MD MBA, ${ }^{9}$ Philip L. Felgner PhD,${ }^{3}$ Saahir Khan MD PhD ${ }^{10 *}$

\section{Author Affiliations}

1. Department of Surgery, University of California Irvine Health, Orange, CA

2. Institute for Clinical and Translational Sciences, University of California Irvine, Irvine, CA

3. Department of Physiology and Biophysics, University of California Irvine, Irvine, CA

4. School of Medicine, University of California Irvine, Irvine, CA

5. Department of Pharmaceutical Sciences, University of California Irvine, Irvine, CA

6. Department of Pathology, University of California Irvine Health, Orange, CA

7. Department of Surgery, University of Southern California, Los Angeles, CA

8. Department of Medicine, University of California Irvine Health, Orange, CA

9. Departments of Surgery and Medicine, Weill Cornell Medicine, New York, NY

10. Department of Medicine, University of Southern California, Los Angeles, CA

\section{* Corresponding Author:}

Saahir Khan, MD, PhD

Division of Infectious Diseases, Department of Medicine

Keck School of Medicine, University of Southern California

2020 Zonal Ave. Rm. 433, Los Angeles, CA 90033

(323) 409-4415

saahirkh@usc.edu

\section{Key Points:}

SARS-CoV-2 seropositivity risk factors amongst health care workers included male gender, nonoccupational exposure, food or environmental services role, and COVID-19 unit location. Those missed by occupational screening were younger, in roles without direct patient care, or exposed outside of work.

Key Words: Coronavirus disease 2019, Severe acute respiratory syndrome coronavirus-2, health care worker, antibody, hospital epidemiology

Word Count: 2,750 


\begin{abstract}
Background: Protecting health care workers (HCWs) during the coronavirus disease 2019 (COVID-19) pandemic is essential. Serologic testing can identify HCWs who had minimally symptomatic severe acute respiratory syndrome coronavirus-2 (SARS-CoV-2) infections that were missed by occupational screening based on daily symptom and temperature checks. Recent studies report conflicting results regarding the impact of occupational factors on SARS-CoV-2 seropositivity amongst HCWs.

Methods: The study population included all hospital workers at an academic medical center in Orange County, California. SARS-CoV-2 seropositivity was assessed from a fingerstick blood specimen using a coronavirus antigen microarray, which compares IgM and IgG antibodies against a panel of SARS-CoV-2 antigens with positive and negative controls to identify prior SARS-CoV2 infection with 98\% specificity and 93\% sensitivity. Demographic, occupational, and clinical factors were surveyed and their effect on seropositivity estimated using multivariable logistic regression analysis.

Results: Amongst 1,557 HCWs with complete data, SARS-CoV-2 seropositivity was 10.8\%. Risk factors for increased seropositivity included male gender, exposure to COVID-19 outside of work, working in food or environmental services, and working in COVID-19 units. Amongst the 1,103 HCW who were seropositive but missed by occupational screening, additional risk factors included younger age and working in administration.

Conclusions: SARS-CoV-2 seropositivity is significantly higher than reported case counts even amongst HCWs who are meticulously screened. Seropositive HCWs missed by occupational screening were more likely to be younger, work roles without direct patient care, or have COVID19 exposure outside of work.
\end{abstract}




\section{Background}

Protecting health care workers (HCWs) during the coronavirus disease 2019 (COVID-19) pandemic is essential to mounting an effective response, as outbreaks among this population could potentially cripple health care delivery. Current case identification relies on symptom and temperature screening with follow-up testing by severe acute respiratory syndrome coronavirus-2 (SARS-CoV-2) reverse transcriptase-polymerase chain reaction (rt-PCR). This approach underestimates disease prevalence due to the high proportion of asymptomatic infections and the impaired sensitivity of rt-PCR due to suboptimal timing, flawed specimen collection, overamplification, or low viral load[1,2]. Given the importance of asymptomatic persons in the dissemination of SARS-CoV-2, identification of risk factors that may augment identification of asymptomatic infection in HCWs is crucial to protecting patients and the health care system[1].

Serologic testing can help to determine the true cumulative prevalence of COVID-19 by identifying previously infected persons who had minimal symptoms so were missed by the current testing paradigm[3, 4]. Multiple COVID-19 seroprevalence studies have been performed in different populations but are limited by low specificity in low-prevalence populations or potential selection bias from the use of convenience sampling[5-10]. Estimated seroprevalence among $\mathrm{HCW}$ varies widely, with some studies finding similar or even lower prevalence compared to the surrounding community[7, 11-14].

Risk factors for SARS-CoV-2 infection amongst HCW were initially extrapolated from studies of hospitalized patients with severe disease that may not be generalizable to the population at large[15]. Early studies to identify risk factors amongst HCWs were performed in early outbreak setting prior to current infection control practices so may not be currently applicable[16, 17]. More recent studies have conflicting results as to whether occupational exposures confer an increased risk of SARS-CoV-2 seropositivity and are limited by heterogeneity and suboptimal performance of the assays and inadequate control for confounding[18, 19].

This study measured SARS-CoV-2 seropositivity amongst 1,557 HCWs at the University of California-Irvine Health, a 418-bed academic medical center in Orange County, California, from May 15 th to June 30th 2020, using a novel coronavirus antigen microarray (CoVAM). This CoVAM utilizes 11 SARS-CoV-2 antigens to determine prior infection with $98 \%$ specificity and 93\% sensitivity based on validation in 91 rt-PCR-positive cases and 88 pre-pandemic negative controls[20]. This performance and level of validation compares favorably to other serologic assays based on a single antigen[21-23]. A digital survey collected data on potential demographic, occupational, and clinical risk factors for SARS-CoV-2 infection. A multivariable analysis tested the null hypothesis that demographic, clinical, and occupational risk factors do not affect SARSCoV-2 seropositivity among HCWs.

\section{Methods}

\section{Study Design, Setting, and Population}

The study was approved by the Institutional Review Board of the University of CaliforniaIrvine under Protocol HS 2020-5818. All employees who worked in the hospital were eligible. Universal daily symptom and temperature screening was initiated on April 14, 2020, with subsequent immediate rt-PCR testing for any HCW with symptoms or fever or disclosure of a confirmed or suspected COVID-19 contact. A primary study site in the main hospital building was open from May 15 to May 29, 2020 to all employees who provided electronic consent (open 
enrollment cohort). In addition, all employees who had been tested for SARS-CoV-2 by rt-PCR due to symptoms or possible exposure, or who provided direct patient care in COVID-19 clinical units or similar control units, were invited via email and provided electronic consent to participate at a secondary study open from May 15 to June 30, 2020 (targeted enrollment cohort). This second cohort was included to enrich the study for HCW with COVID-19 infection, symptoms, or exposure.

\section{Study Procedures}

Participants were given a unique study identifier and a mobile phone link to a Research Electronic Data Capture (REDCap, Vanderbilt University, Nashville, TN) survey to collect data on demographic, clinical, and occupational risk factors (Appendix A). At the primary study site, participants then underwent capillary blood collection via fingerstick using a disposable lancet into microfuge capillary tubes. After centrifugation at $1500 \mathrm{x}$ g for $10 \mathrm{~min}$, supernatant plasma was collected, frozen, and transported for laboratory analysis. At the secondary study site, participants underwent phlebotomy into gold-top tubes (BD Biosciences, San Jose, CA) for centrifugation and collection of serum, from which an aliquot was frozen and transported for laboratory analysis. All specimens were labeled with unique identifiers accessible only via a secure key.

\section{Laboratory Assays}

The CoVAM includes 67 antigens from respiratory viruses, including 11 antigens from SARS-CoV-2 (Sino Biological U.S. Inc., Wayne, PA). Antigens were printed onto microarrays in quadruplicate, probed with serum specimens and secondary antibodies for IgM and IgG, and imaged to determine background-subtracted median fluorescence intensity[24-26]. Briefly, CoVAM data for each specimen were compared with 91 rt-PCR-positive cases with blood collected $\geq 7 \mathrm{~d}$ (range, 7-50 d, median $11 \mathrm{~d}$ ) post-symptom onset and 88 pre-pandemic controls with blood collected prior to November 1, 2019, which were split randomly into $70 \%$ derivation and $30 \%$ validation cohorts. Based on IgM and IgG antibodies against the 11 SARS-CoV-2 antigens on the array, a linear regression model was trained on positive and negative controls in the derivation cohort to determine optimal weighted combinations of reactive antigens to calculate composite SARS-CoV-2 antibody titers that discriminate the two groups, with reactivity thresholds selected to achieve maximum sensitivity while maintaining $\geq 98 \%$ specificity. The model was tested on the validation cohort and achieved $92.7 \%$ sensitivity and $97.7 \%$ specificity for detecting prior SARS-CoV-2 infection based on composite IgM or IgG positivity.

\section{$\underline{\text { Statistical Analysis }}$}

SARS-CoV-2 seropositivity was calculated as the proportion of HCWs who were classified as seropositive in the study population and within categories of each demographic, clinical and occupational risk factor, expressed as the odds ratio (OR) with 95\% confidence interval compared to the study population. In order to assess the associations between clinical and occupational risk factors and seropositivity, multivariable models were constructed to control for potential confounding due to demographic and health-related factors associated with both occupational exposure and underlying risk for seropositivity. We forced demographic variables into the model a priori, which included age, gender, and race/ethnicity, which have well-established associations with occupation and health outcomes. Health-related covariates included comorbidities (asthma or COPD, diabetes mellitus, hypertension, self-reported smoking or vaping) and known COVID-19 exposure outside of work, which would likely influence seropositivity. Occupation-related 
variables included self-reported role, location, and COVID-19 patient contact. Health- and occupation-related exposures were selected based on bivariate associations with seropositivity using a $\mathrm{p}<0.1$ criterion for inclusion. The final model for clinical and occupational risk factors was adjusted for age (quartiles), gender, race/ethnicity (Asian, White, Latino, Black, and Mixed/other/not reported), known COVID-19 exposure outside of work, and workplace role, location, and COVID-19 patient contact. Adjusted analyses were conducted among the entire sample and replicated among the subgroup of HCWs not tested previously via rt-PCR. Model fit was evaluated using the Hosmer-Lemeshow goodness-of-fit test and C-statistic. All analyses were conducted using R software v4.0.3 (R Consortium for Statistical Computing, Vienna, Austria).

\section{Results}

Study Population

From an eligible population of 5,349 HCWs, 1,841 (34.4\%) consented to participate, including 1,108 in the open enrollment cohort and 733 in the targeted enrollment cohort. Of the targeted cohort, 343 had been tested by rt-PCR for COVID-19, 237 worked in a COVID-19 unit and 153 worked in a matched control unit of similar acuity. A total of 1,557 HCWs completed the survey and provided blood specimens to be analyzed by CoVAM, including 1,044 in the open enrollment cohort and 513 in the targeted cohort. Compared to the population of Orange County, the study population has a higher proportion of females and Asian race/ethnicity.

SARS-CoV-2 seropositivity was $10.8 \%$ in the overall HCW cohort (Table 1). Seropositivity was $17.7 \%$ amongst the $419 \mathrm{HCW}$ s who had been tested by rt-PCR previously, and $8.0 \%$ among the $1,138 \mathrm{HCW}$ who had not. Seropositivity in the targeted versus open enrollment cohorts matched closely the seropositivity among HCWs tested previously versus not tested by rtPCR respectively, indicating that the difference between the cohorts is largely driven by rt-PCR testing. Of the $343 \mathrm{HCW}$ tested by rt-PCR, 38 were PCR+ and 322 PCR-, with 36 (94.4\%) of the $\mathrm{PCR}+$ testing seropositive whereas $30(9.3 \%)$ of the PCR- were seropositive, higher than the seropositivity rate of those not tested by rt-PCR (Supplementary Table 4).

Potential demographic risk factors included age, gender, race/ethnicity, and co-morbid conditions, as well as confirmed SARS-CoV-2 exposure outside the hospital (Table 1). No significant effect of age was noted among HCWs overall; however, a non-significant increase in seropositivity was observed for younger HCWs who were not previously tested by rt-PCR, indicating that younger HCW with SARS-CoV-2 infection may be less likely to screen positive for symptoms and be tested by rt-PCR. Male gender was associated with increased seropositivity, whereas race/ethnicity and co-morbidities were not. Confirmed COVID-19 exposure outside the hospital was the most significant demographic risk factor for seropositivity, with a higher OR among HCWs not tested by rt-PCR. These data indicate that either exposures occurred prior to widespread availability of rt-PCR testing which is unlikely given implementation of universal employee screening and testing early in the course of the local epidemic, or more likely that HCW were not always accurately reporting COVID-19 exposures during screening.

\section{Impact of Occupational Risk Factors on SARS-CoV-2 Seropositivity}

Among roles within the hospital, only HCWs working in food services or environmental services showed significantly increased seropositivity as compared to the overall HCW population, and the effect was restricted to those not tested by rt-PCR. Similarly, working in administration was associated with increased seropositivity only amongst HCWs not tested by rt-PCR. Among 
locations in the hospital, working in COVID-19 units was associated with increased seropositivity, whereas working in labor and delivery units was associated with decreased seropositivity. COVID19 patient contact and participation in aerosol-generating procedures on these patients were not associated with seropositivity.

Multivariable analyses included the non-occupational covariates discussed above, in addition to role and location within the hospital (Table 2). The Hosmer-Lemeshow goodness-offit test was non-significant $(\mathrm{p}=0.55)$ and area under the receiver-operating characteristic curve showed moderate discriminant ability $(\mathrm{C}$-statistic $=0.62)$, indicating that the adjusted model fit the data well.

\section{Correlation of COVID-19 Symptoms with Seropositivity}

A separate multivariable analysis was conducted that included non-occupational covariates discussed above, in addition to symptoms of COVID-19 (Table 3). Overall, multiple symptoms (fatigue, myalgias, fever, chills, and anosmia) were associated with increased seropositivity, with the strongest association observed for anosmia. These associations were entirely restricted to HCW tested previously by rt-PCR, indicating that occupational health screening was indeed effective in identifying symptomatic infections.

\section{Discussion}

This study provides several insights into the relationships between non-occupational and occupational risk factors and COVID-19 seropositivity among HCWs (Figure 1). Exposure to COVID-19 outside of work was a greater risk factor for seropositivity than any occupational exposure other than working in food or environmental services. The HCW roles associated with the greatest risk of seropositivity did not involve direct patient care. Nurses, who have the most direct and sustained patient contact, were not at significantly increased risk. The only locations associated with increased seropositivity were the dedicated COVID-19 ICU and floor units. The operating room, an area of great concern due to intubation of multiple patients, was not associated with increased risk. Performing aerosol-generating procedures on known COVID-19 patients was also not significantly associated with seropositivity, which is reassuring given that perceived risk of transmission during these procedures can delay patient care.

Stratification of HCWs based on whether or not they were tested previously by rt-PCR yielded several additional insights into the strengths and weaknesses of universal symptom screening. The association between COVID-19 symptoms and seropositivity was restricted to HCW tested previously by rt-PCR, indicating that universal screening was effective in identifying symptomatic infections. Younger HCWs who were COVID-19-seropositive were more likely to be missed by occupational screening, which is consistent with the increased prevalence of minimally symptomatic infection among younger individuals[27]. Decreased seropositivity among $\mathrm{HCW}$ in labor and delivery units may be due to increased vigilance amongst $\mathrm{HCW}$ who care for pregnant patients or low disease prevalence among these patients. While the hospital's mandatory screening was only implemented one month prior to this study, the prevalence of COVID-19 in Orange County was low at that time and increased subsequently (Figure 2). The CoVAM was trained and validated on blood specimens collected relatively soon after symptom onset (minimum $7 \mathrm{~d}$, median $11 \mathrm{~d}$ ) consistent with known kinetics of the antibody response to COVID-19 [3]. Therefore, we believe the effects of occupational health screening are at least partially captured in our analysis. In addition, the study hospital was able to maintain infection 
prevention best practices consistent with guidance from the U.S. Centers for Disease Control and Prevention (CDC), including continuous, ample availability of PPE throughout the pandemic.

No data were available for SARS-CoV-2 seropositivity in the surrounding community at the time that the study was performed. The cumulative COVID-19 prevalence in Orange County at the time of this study's enrollment was $0.2 \%$. The overall seropositivity rate was $10.8 \%$ in this study, but the $8.0 \%$ seropositivity amongst HCW not previously identified by screening, which matches the seropositivity in the open enrollment cohort, is most appropriate for comparison to community prevalence to avoid the enrichment effect of the targeted enrollment cohort. This seropositivity is 40 -fold higher than community prevalence as determined by rt-PCR testing (Figure 2). Whereas more recent seroprevalence studies show a 10-fold increase compared to case counts, our result is most comparable to early seroprevalence studies prior to significant local outbreaks of COVID-19 that have found larger disparities between seropositivity rates and case counts[5-9, 13]. Recently, a community study sampled 2,979 random participants in Orange County from July 10 through August 16, 2020 and found a seropositivity rate of $11.5 \%$ using an updated version of the CoVAM with a more stringent threshold for seropositivity[28]. Taken together, these observations imply that $\mathrm{HCW}$ are not more likely to be seropositive than the surrounding community, although the different study periods limit this direct comparison.

The findings of this study are largely consistent with recently published studies of COVID19 seropositivity among $\operatorname{HCWs}[18,19]$. In particular, the lack of association of either race/ethnicity or co-morbidities with seropositivity in our study is consistent with these prior HCW studies and differs from a prior community study that did observe such associations[29]. This study provides additional insight compared to prior studies by examining specific roles in the hospital and controlling for multiple likely sources of confounding. For example, nurses had significantly elevated seropositivity in bivariate analyses (unadjusted $\mathrm{OR}[\mathrm{CI}]=1.52[1.10-2.10]$ ) but this finding did not persist after adjusting for work location; in contrast, null associations between seropositivity and roles without direct patient care became significant and positive after adjusting for location (unadjusted OR [CI] for administrative $=1.08[0.66,1.69]$; food/environmental $=1.54$ [0.62-3.29]) .

Strengths of this study include the validated test performance of the CoVAM, which compares favorably to currently available single-antigen assays; the large sample size with inclusion of $34.4 \%$ of $\mathrm{HCW}$ at the hospital; and the use of multivariable analysis to control for confounding. The weaknesses of this study include the non-random enrollment methodology as the targeted enrollment cohort was invited from groups expected to have higher seroprevalence and the open enrollment cohort was subject to self-selection, which both could lead to sampling bias. Also, different blood sampling methodology was used in the open and targeted enrollment cohorts due to institutional interest in banking specimens from the latter group. The subgroup analysis based on prior rt-PCR testing was used to control for the heterogeneous sampling, as prior testing was the primary driver of increased prevalence in the targeted enrollment cohort. When the study population is stratified based on method of recruitment (Supplementary Tables 1-3), the results are largely similar to stratification based on rt-PCR testing (Tables 1-3).

The results of this study have several implications for the local and global responses to the COVID-19 pandemic. The finding of a significantly increased SARS-CoV-2 prevalence by serology as compared with rt-PCR provides evidence that the reported counts of confirmed COVID-19 cases are significant underestimates. The observations that HCWs who are younger, work in non-patient care roles, or have COVID-19 exposure outside of work are more likely to have COVID-19 seropositivity without prior testing indicates that screening and vaccination 
medRxiv preprint doi: https://doi.org/10.1101/2020.12.17.20248430; this version posted December 19, 2020. The copyright holder for this preprint (which was not certified by peer review) is the author/funder, who has granted medRxiv a license to display the preprint in perpetuity.

It is made available under a CC-BY-NC 4.0 International license .

efforts need to focus on these groups. The lack of association of aerosol-generating procedures with COVID-19 seropositivity in the context of adequate availability and presumably appropriate use of PPE is reassuring. The increased seropositivity in COVID-19 units is less reassuring but may potentially be explained by employee-to-employee spread in these locations given that caring for COVID-19 patients was not a significant risk factor. Further studies that include longitudinal follow-up are needed to confirm these observations. 


\section{Author Contributions}

The study was designed by S. Schubl and S. Khan and coordinated by C. Figueroa, and study procedures were conducted by D. Brabender, A. Naaseh, O. Dominguez, A. Runge, S. Skochko, and J. Chinn. Blood specimens were processed by P. Horvath under the supervision of F. Zaldivar and by D. Tifrea under the supervision of R. Edwards. The coronavirus antigen microarray was designed by S. Khan and P. Felgner and was constructed by R. Nakajima. The testing of specimens on the coronavirus antigen microarray was performed by A. Jain under the supervision of S. Khan and P. Felgner and A. Kelsey and K. Lai under the supervision of W. Zhao. The CoVAM data was analyzed by R. de Assis under the supervision of S. Khan and P. Felgner. The study data was collated by C. Figueroa and A. Gonzales and analyzed by A. Palma and A. Grigorian. The data was interpreted and the manuscript and figures were prepared by S. Khan, S. Schubl, and A. Palma with substantial input from M. Stamos, A. Amin and P. Barie and additional input and approval from all other authors.

\section{Acknowledgements}

This work was supported by two intramural research grants from the COVID-19 Basic, Translational, and Clinical Research Fund of the University of California Irvine and by the Emergency COVID-19 Research Seed Funding Opportunity from the University of California Office of the President [research grants R00RG2646, R01RG3745]. The findings and conclusions in this report are those of the authors and do not necessarily represent the official position or policy of the University of California.

This work utilized the Chao Family Comprehensive Cancer Center Experimental Tissue Shared Resource, supported by the National Cancer Institute of the National Institutes of Health [award number P30CA062203].

S. Khan was supported by the National Center for Research Resources and the National Center for Advancing Translational Sciences of the National Institutes of Health [grant KL2 TR001416]. The project described was supported by the National Center for Research Resources and the National Center for Advancing Translational Sciences of the National Institutes of Health [grant UL1 TR001414]. The content is solely the responsibility of the authors and does not necessarily represent the official views of the NIH.

The initial design and construction of the CoVAM was supported by the Prometheus-UMD contract sponsored by the Defense Advanced Research Projects Agency (DARPA) BTO under the auspices of Col. Matthew Hepburn [agreements N66001-17-2-4023, N66001-18-2-4015]. The findings and conclusions in this report are those of the authors and do not necessarily represent the official position or policy of the funding agencies and no official endorsements should be inferred.

\section{Conflicts of Interest}

The coronavirus antigen microarray is intellectual property of the Regents of the University of California that is licensed for commercialization to Nanommune Inc. (Irvine, CA), a private company for which P. Felgner is the largest shareholder and several co-authors (R. de Assis, A. Jain, R. Nakajima, and S. Khan) also own shares. Nanommune Inc. has a business partnership with Sino Biological Inc. (Beijing, China) which expressed and purified the antigens used in this study. 
A. Amin reports serving as a clinical trials investigator for NIH/NIAID, NeuroRx Pharma, Pulmotect, Blade Therapeutics, Novartis, Takeda, Humanigen, Eli-Lilly, PTC Therpeutics, OctaPharma, Fulcrum Therapeutics, and Alexion, and has served as a consultant and/or speaker for Bristol-Meyers-Squibb, Pfizer, Boehringer Ingelheim, Portola, Sunovion, Mylan, Salix, Alexion, Astra Zeneca, Novartis, Nabriva, Paratek, Bayer, Tetraphase, Achogen, LaJolla, Millenium, Aseptiscope, HeartRite, and Sprightly Health.

\section{Materials and Correspondence}

Please address all correspondence and material requests related to this manuscript to Saahir Khan (saahirkh@usc.edu). The dataset generated by testing specimens on the coronavirus antigen microarray and the analysis code applied to this dataset is available upon request. The associated clinical data with removal of all identifying information is also available upon request. 


\section{References}

1. Lavezzo E, Franchin E, Ciavarella C, et al. Suppression of a SARS-CoV-2 outbreak in the Italian municipality of Vo'. Nature $\mathbf{2 0 2 0 .}$

2. Tang YW, Schmitz JE, Persing DH, Stratton CW. The Laboratory Diagnosis of COVID19 Infection: Current Issues and Challenges. J Clin Microbiol 2020.

3. Zhao J, Yuan Q, Wang H, et al. Antibody responses to SARS-CoV-2 in patients of novel coronavirus disease 2019. Clin Infect Dis 2020.

4. To KK, Tsang OT, Leung WS, et al. Temporal profiles of viral load in posterior oropharyngeal saliva samples and serum antibody responses during infection by SARSCoV-2: an observational cohort study. Lancet Infect Dis 2020.

5. Stringhini S, Wisniak A, Piumatti G, et al. Seroprevalence of anti-SARS-CoV-2 IgG antibodies in Geneva, Switzerland (SEROCoV-POP): a population-based study. Lancet 2020.

6. Sood N, Simon P, Ebner P, et al. Seroprevalence of SARS-CoV-2-Specific Antibodies Among Adults in Los Angeles County, California, on April 10-11, 2020. JAMA 2020.

7. Garcia-Basteiro AL, Moncunill G, Tortajada M, et al. Seroprevalence of antibodies against SARS-CoV-2 among health care workers in a large Spanish reference hospital. medRxiv 2020: 2020.04.27.20082289.

8. Bendavid E, Mulaney B, Sood N, et al. COVID-19 Antibody Seroprevalence in Santa Clara County, California. medRxiv 2020: 2020.04.14.20062463.

9. Havers FP, Reed C, Lim T, et al. Seroprevalence of Antibodies to SARS-CoV-2 in 10 Sites in the United States, March 23-May 12, 2020. JAMA Internal Medicine 2020.

10. Vogel G. First antibody surveys draw fire for quality, bias. Science 2020; 368(6489): 350-1.

11. Chu J, Yang N, Wei Y, et al. Clinical Characteristics of 54 medical staff with COVID-19: A retrospective study in a single center in Wuhan, China. J Med Virol 2020.

12. Schwartz J, King CC, Yen MY. Protecting Health Care Workers during the COVID-19 Coronavirus Outbreak -Lessons from Taiwan's SARS response. Clin Infect Dis 2020.

13. Korth J, Wilde B, Dolff S, et al. SARS-CoV-2-specific antibody detection in healthcare workers in Germany with direct contact to COVID-19 patients. J Clin Virol 2020; 128: 104437.

14. Self WH, Tenforde MW, Stubblefield WB, et al. Seroprevalence of SARS-CoV-2 Among Frontline Health Care Personnel in a Multistate Hospital Network - 13 Academic Medical Centers, April-June 2020. MMWR Morb Mortal Wkly Rep 2020; 69(35): 12216.

15. Liang W, Liang H, Ou L, et al. Development and Validation of a Clinical Risk Score to Predict the Occurrence of Critical Illness in Hospitalized Patients With COVID-19. JAMA Intern Med 2020.

16. Lai X, Wang M, Qin C, et al. Coronavirus Disease 2019 (COVID-2019) Infection Among Health Care Workers and Implications for Prevention Measures in a Tertiary Hospital in Wuhan, China. JAMA Netw Open 2020; 3(5): e209666.

17. Boccia S, Ricciardi W, Ioannidis JPA. What Other Countries Can Learn From Italy During the COVID-19 Pandemic. JAMA Intern Med 2020.

18. Steensels D, Oris E, Coninx L, et al. Hospital-Wide SARS-CoV-2 Antibody Screening in 3056 Staff in a Tertiary Center in Belgium. JAMA 2020. 
medRxiv preprint doi: https://doi.org/10.1101/2020.12.17.20248430; this version posted December 19, 2020. The copyright holder for this preprint (which was not certified by peer review) is the author/funder, who has granted medRxiv a license to display the preprint in perpetuity.

It is made available under a CC-BY-NC 4.0 International license .

19. Moscola J, Sembajwe G, Jarrett M, et al. Prevalence of SARS-CoV-2 Antibodies in Health Care Personnel in the New York City Area. JAMA 2020.

20. Assis RRd, Jain A, Nakajima R, et al. Analysis of SARS-CoV-2 Antibodies in COVID19 Convalescent Plasma using a Coronavirus Antigen Microarray. bioRxiv 2020: 2020.04.15.043364.

21. Liu W, Liu L, Kou G, et al. Evaluation of Nucleocapsid and Spike Protein-based ELISAs for detecting antibodies against SARS-CoV-2. J Clin Microbiol 2020.

22. Center for Health Security, Johns Hopkins University. Available at: https://www.centerforhealthsecurity.org/resources/COVID-19/serology/Serology-basedtests-for-COVID-19.html. Accessed June 152020.

23. Zhou W, Wang W, Wang H, Lu R, Tan W. First infection by all four non-severe acute respiratory syndrome human coronaviruses takes place during childhood. BMC Infect Dis 2013; 13: 433.

24. Jain A, Taghavian O, Vallejo D, et al. Evaluation of quantum dot immunofluorescence and a digital CMOS imaging system as an alternative to conventional organic fluorescence dyes and laser scanning for quantifying protein microarrays. Proteomics 2016; 16(8): 1271-9.

25. Nakajima R, Supnet M, Jasinskas A, et al. Protein Microarray Analysis of the Specificity and Cross-Reactivity of Influenza Virus Hemagglutinin-Specific Antibodies. mSphere 2018; 3(6).

26. Khan S, Jain A, Taghavian O, et al. Use of an Influenza Antigen Microarray to Measure the Breadth of Serum Antibodies Across Virus Subtypes. J Vis Exp 2019; (149).

27. Davies NG, Klepac P, Liu Y, et al. Age-dependent effects in the transmission and control of COVID-19 epidemics. Nat Med 2020; 26(8): 1205-11.

28. Bruckner TA, Parker DM, Bartell SM, et al. Estimated Seroprevalence of SARS-CoV-2 Antibodies Among Adults in Orange County, California. medRxiv 2020: 2020.10.07.20208660.

29. Rosenberg ES, Tesoriero JM, Rosenthal EM, et al. Cumulative incidence and diagnosis of SARS-CoV-2 infection in New York. Ann Epidemiol 2020; 48: 23-9.e4. 
medRxiv preprint doi: https://doi.org/10.1101/2020.12.17.20248430; this version posted December 19, 2020. The copyright holder for this preprint (which was not certified by peer review) is the author/funder, who has granted medRxiv a license to display the preprint in perpetuity.

It is made available under a CC-BY-NC 4.0 International license .

\section{Tables}

Table 1. Association between demographic and health-related characteristics and SARS-CoV-2 seropositivity (AB prevalence) of HCW study population and subgroups segregated by prior rtPCR testing. (COPD, chronic obstructive pulmonary disease)

\begin{tabular}{|c|c|c|c|c|c|c|c|c|c|}
\hline Parameter & $\begin{array}{l}\text { HCWs, } \mathrm{n} \\
(\%)\end{array}$ & $\begin{array}{c}\text { All HCWs (n= } \\
\text { COVID-19 } \\
\text { AB } \\
\text { prevalence, } \\
\text { n (\%) }\end{array}$ & OR $(95 \% \mathrm{CI})^{1}$ & $\begin{array}{l}\text { Not } \\
\text { HCWs, n } \\
(\%)\end{array}$ & $\begin{array}{c}\text { sted by rt-PC } \\
\text { COVID-19 } \\
\text { AB } \\
\text { prevalence, } \\
\text { n (\%) } \\
\end{array}$ & $\begin{array}{l}(\mathrm{n}=1,138) \\
\quad \text { OR }(95 \% \mathrm{CI})^{1}\end{array}$ & $\begin{array}{l}\text { HCWs, n } \\
(\%)\end{array}$ & $\begin{array}{c}\text { sted by rt-PC } \\
\text { COVID-19 } \\
\text { AB } \\
\text { prevalence, } \\
\text { n (\%) } \\
\end{array}$ & $\begin{array}{l}(\mathrm{n}=419) \\
\quad \text { OR }(95 \% \mathrm{CI})^{1}\end{array}$ \\
\hline Total & $1557(100)$ & $165(10.6)$ & & $\begin{array}{l}1138 \\
(100)\end{array}$ & $91(8.0)$ & & $419(100)$ & $74(17.7)$ & \\
\hline \multicolumn{10}{|l|}{ Age quartiles (y) } \\
\hline $18-31$ & $418(26.8)$ & 49 (11.7) & $1.17(0.82-1.66)$ & $311(27.3)$ & $33(10.6)$ & $1.57(1.00-2.45)$ & $\begin{array}{c}107 \\
(25.5)\end{array}$ & $16(15.0)$ & $0.77(0.41-1.38)$ \\
\hline $32-38$ & $382(24.5)$ & $41(10.7)$ & $1.02(0.69-1.47)$ & $257(22.6)$ & $22(8.6)$ & $1.10(0.65-1.79)$ & $\begin{array}{c}125 \\
(29.8)\end{array}$ & $19(15.2)$ & $0.78(0.43-1.36)$ \\
\hline $39-43$ & $377(24.2)$ & $35(9.3)$ & $0.83(0.55-1.21)$ & $275(24.2)$ & $15(5.5)$ & $0.60(0.33-1.03)$ & $\begin{array}{c}102 \\
(24.3)\end{array}$ & $20(19.6)$ & $1.19(0.66-2.07)$ \\
\hline $49-73$ & $380(24.4)$ & $40(10.5)$ & $0.99(0.67-1.43)$ & $295(25.9)$ & $21(7.1)$ & $0.85(0.50-1.38)$ & $85(20.3)$ & $19(22.4)$ & $1.46(0.80-2.59)$ \\
\hline \multicolumn{10}{|l|}{ Gender } \\
\hline Female & $1073(68.9)$ & $100(9.3)$ & $0.66(0.48-0.93)$ & $781(68.6)$ & $57(7.3)$ & $0.75(0.48-1.18)$ & $\begin{array}{c}292 \\
(69.7)\end{array}$ & $43(14.7)$ & $0.53(0.32-0.90)$ \\
\hline Male & $482(31.0)$ & $64(13.3)$ & $1.48(1.05-2.06)$ & $355(31.2)$ & $33(9.3)$ & $1.28(0.81-1.99)$ & $\begin{array}{c}127 \\
(30.3)\end{array}$ & $31(24.4)$ & $1.87(1.11-3.13)$ \\
\hline Other $^{2}$ & $2(0.1)$ & $1(50.0)$ & - & $2(0.2)$ & $1(50.0)$ & - & $0(0)$ & - & - \\
\hline \multicolumn{10}{|l|}{ Race/ethnicity } \\
\hline Asian & $608(39.0)$ & $70(11.5)$ & $1.17(0.84-1.62)$ & $415(36.5)$ & $26(6.3)$ & $0.68(0.42-1.07)$ & $\begin{array}{c}193 \\
(46.1)\end{array}$ & $44(22.8)$ & $1.93(1.16-3.24)$ \\
\hline White & $457(29.4)$ & $46(10.1)$ & $0.92(0.64-1.31)$ & $336(29.5)$ & $32(9.5)$ & $1.33(0.84-2.07)$ & $\begin{array}{c}121 \\
(28.9)\end{array}$ & 14 (11.6) & $0.52(0.27-0.94)$ \\
\hline Latino & $286(18.4)$ & $27(9.4)$ & $0.86(0.54-1.30)$ & $232(20.4)$ & $18(7.8)$ & $0.96(0.55-1.61)$ & $54(12.9)$ & $9(16.7)$ & $0.92(0.41-1.90)$ \\
\hline Black & $29(1.9)$ & $3(10.3)$ & $0.97(0.23-2.80)$ & $25(2.2)$ & $2(8.0)$ & $1.00(0.16-3.46)$ & $4(1.0)$ & $1(25.0)$ & $1.56(0.08-12.39)$ \\
\hline $\begin{array}{l}\text { Mixed/Other/Not } \\
\text { reported }\end{array}$ & $177(11.4)$ & $19(10.7)$ & $1.02(0.60-1.65)$ & $130(11.4)$ & $13(10.0)$ & $1.32(0.68-2.38)$ & 47 (11.2) & $6(12.8)$ & $0.65(0.24-1.50)$ \\
\hline \multicolumn{10}{|l|}{ Comorbidities } \\
\hline Any comorbidities & $370(23.8)$ & $41(11.1)$ & $1.07(0.73-1.54)$ & $258(22.7)$ & $18(7.0)$ & $0.83(0.47-1.39)$ & $\begin{array}{c}112 \\
(26.7)\end{array}$ & $23(20.5)$ & $1.30(0.74-2.22)$ \\
\hline Asthma or COPD & $155(10.0)$ & $16(10.3)$ & $0.97(0.54-1.62)$ & $114(10.0)$ & $9(7.9)$ & $0.98(0.45-1.92)$ & $41(9.8)$ & $7(17.1)$ & $0.96(0.38-2.13)$ \\
\hline Diabetes mellitus & $67(4.3)$ & $10(14.9)$ & $1.51(0.71-2.89)$ & $45(4.0)$ & $3(6.7)$ & $0.82(0.19-2.30)$ & $22(5.3)$ & $7(31.8)$ & $2.30(0.85-5.68)$ \\
\hline Hypertension & $172(11.0)$ & $18(10.5)$ & $0.98(0.57-1.61)$ & $118(10.4)$ & $5(4.2)$ & $0.48(0.17-1.10)$ & $54(12.9)$ & $13(24.1)$ & $1.58(0.77-3.06)$ \\
\hline Smoking or vaping & $37(2.4)$ & $4(10.8)$ & $1.02(0.30-2.61)$ & $24(2.1)$ & $2(8.3)$ & $1.05(0.17-3.63)$ & $13(3.1)$ & $2(15.4)$ & $0.84(0.13-3.23)$ \\
\hline $\begin{array}{l}\text { Known COVID-19 } \\
\text { exposure at home }\end{array}$ & $58(3.7)$ & $12(20.7)$ & $2.29(1.14-4.29)$ & $28(2.5)$ & $5(17.9)$ & $2.59(0.85-6.47)$ & $30(7.2)$ & $7(23.3)$ & $1.46(0.56-3.39)$ \\
\hline
\end{tabular}

${ }^{1}$ Odds ratios (OR) are unadjusted, comparing the selected group to the entire HCW population.

${ }^{2}$ OR for Other gender omitted due to small sample size. 
Table 2. Associations between HCW occupational factors and SARS-CoV-2 seropositivity (AB prevalence) of HCW study population and subgroups segregated by prior rt-PCR testing.

\begin{tabular}{|c|c|c|c|c|c|c|c|c|c|}
\hline \multirow[b]{2}{*}{ Variable } & \multicolumn{3}{|c|}{$\begin{array}{l}\text { All HCWs }(\mathrm{n}=1,557) \\
\text { COVID-19 }\end{array}$} & \multicolumn{3}{|c|}{$\begin{array}{l}\text { Not tested by rt-PCR }(\mathrm{n}=1,138) \\
\text { COVID-19 }\end{array}$} & \multicolumn{3}{|c|}{$\begin{array}{l}\text { Tested by rt-PCR }(\mathrm{n}=419) \\
\text { COVID-19 }\end{array}$} \\
\hline & $\begin{array}{l}\text { HCWs, n } \\
\quad \%)\end{array}$ & $\begin{array}{c}\text { COVID-19 } \\
\text { AB } \\
\text { prevalence, } \\
n(\%) \\
\end{array}$ & $\begin{array}{c}\text { Adjusted OR } \\
(95 \% \mathrm{CI})^{1}\end{array}$ & $\begin{array}{l}\text { HCWs, n } \\
(\%)\end{array}$ & $\begin{array}{c}\text { COVID-19 } \\
\text { AB } \\
\text { prevalence, } \\
\mathrm{n}(\%)\end{array}$ & $\begin{array}{c}\text { Adjusted OR } \\
(95 \% \mathrm{CI})^{1}\end{array}$ & $\begin{array}{l}\text { HCWs, n } \\
(\%)\end{array}$ & $\begin{array}{c}\text { COVID-19 } \\
\text { AB } \\
\text { prevalence, } \\
\text { n (\%) }\end{array}$ & $\begin{array}{c}\text { Adjusted OR } \\
(95 \% \mathrm{CI})^{1}\end{array}$ \\
\hline Total & $1557(100)$ & $165(10.6)$ & & $1138(100)$ & $91(8.0)$ & & $419(100)$ & $74(17.7)$ & \\
\hline \multicolumn{10}{|l|}{ Role $^{2}$} \\
\hline Physician & $246(15.8)$ & $17(6.9)$ & $0.59(0.27-1.29)$ & $183(16.1)$ & $10(5.5)$ & $0.75(0.27-2.15)$ & $63(15.0)$ & $7(11.1)$ & $0.41(0.11-1.49)$ \\
\hline Nurse & $705(45.3)$ & $90(12.8)$ & $1.47(0.81-2.80)$ & $478(42.0)$ & $40(8.4)$ & $1.81(0.81-4.55)$ & $227(54.2)$ & $50(22.0)$ & $1.24(0.49-3.38)$ \\
\hline Student & $69(4.4)$ & $5(7.2)$ & $0.75(0.22-2.20)$ & $64(5.6)$ & $5(7.8)$ & $1.05(0.28-3.59)$ & $5(1.2)$ & $0(0.0)$ & - \\
\hline Ancillary clinical staff & $88(5.7)$ & $7(8.0)$ & $0.91(0.32-2.36)$ & $55(4.8)$ & $4(7.3)$ & $1.48(0.36-5.32)$ & $33(7.9)$ & $3(9.1)$ & $0.46(0.08-2.19)$ \\
\hline Administrative & $205(13.2)$ & $23(11.2)$ & $1.76(0.86-3.69)$ & $164(14.4)$ & $18(11.0)$ & $2.69(1.10-7.10)$ & $41(9.8)$ & $5(12.2)$ & $0.86(0.21-3.30)$ \\
\hline Food/environmental & $46(3.0)$ & $7(15.2)$ & $4.85(1.51-14.85)$ & $37(3.3)$ & $6(16.2)$ & $8.28(2.16-31.48)$ & $9(2.1)$ & $1(11.1)$ & $1.52(0.06-17.75)$ \\
\hline Other & $199(12.8)$ & $16(8.0)$ & $0.70(0.39-1.18)$ & $157(13.8)$ & $8(5.1)$ & $0.54(0.24-1.09)$ & $42(10.0)$ & $8(19.0)$ & $1.19(0.48-2.65)$ \\
\hline \multicolumn{10}{|l|}{ Location $^{3}$} \\
\hline COVID ICU & $171(11.0)$ & $26(15.2)$ & $2.28(1.29-3.96)$ & $100(8.8)$ & $10(10.0)$ & $2.35(0.97-5.32)$ & $71(16.9)$ & $16(22.5)$ & $1.65(0.71-3.79)$ \\
\hline Non-COVID ICU & $364(23.4)$ & $38(10.4)$ & $0.89(0.56-1.39)$ & $258(22.7)$ & $18(7.0)$ & $0.77(0.40-1.40)$ & $106(25.3)$ & $20(18.9)$ & $1.04(0.49-2.16)$ \\
\hline COVID floor & $261(16.8)$ & $35(13.4)$ & $1.59(1.01-2.48)$ & $133(11.7)$ & $10(7.5)$ & $1.21(0.51-2.60)$ & $128(30.5)$ & $25(19.5)$ & $1.26(0.67-2.35)$ \\
\hline Non-COVID floor & $436(28.0)$ & $50(11.5)$ & $1.26(0.85-1.85)$ & $309(27.2)$ & $21(6.8)$ & $0.85(0.47-1.47)$ & $127(30.3)$ & $29(22.8)$ & $2.63(1.40-4.97)$ \\
\hline Labor and delivery & $113(7.3)$ & $4(3.5)$ & $0.24(0.06-0.72)$ & $88(7.7)$ & $4(4.5)$ & $0.50(0.12-1.56)$ & $25(6.0)$ & $0(0.0)$ & - \\
\hline Operating room & $196(12.6)$ & $15(7.7)$ & $0.99(0.53-1.78)$ & $173(15.2)$ & $13(7.5)$ & $1.13(0.55-2.17)$ & $23(5.5)$ & $2(8.7)$ & $0.76(0.11-3.43)$ \\
\hline Non-operating room procedural & $198(12.7)$ & $16(8.1)$ & $0.91(0.49-1.59)$ & $155(13.6)$ & $14(9.0)$ & $1.44(0.72-2.74)$ & $43(10.3)$ & $2(4.7)$ & $0.36(0.05-1.34)$ \\
\hline Emergency department & $250(16.1)$ & $20(8.0)$ & $0.70(0.40-1.18)$ & $199(17.5)$ & $13(6.5)$ & $0.62(0.31-1.19)$ & $51(12.2)$ & $7(13.7)$ & $1.02(0.36-2.67)$ \\
\hline Outpatient clinical unit & $188(12.1)$ & $13(6.9)$ & $0.70(0.36-1.27)$ & $143(12.6)$ & $8(5.6)$ & $0.72(0.30-1.53)$ & $45(10.7)$ & $5(11.1)$ & $0.63(0.19-1.73)$ \\
\hline Non-clinical unit & $249(16.0)$ & $21(8.4)$ & $0.70(0.37-1.24)$ & $201(17.7)$ & $18(9.0)$ & $0.76(0.37-1.51)$ & $48(11.5)$ & $3(6.2)$ & $0.47(0.09-1.76)$ \\
\hline \multicolumn{10}{|l|}{ Job-related exposures $^{4}$} \\
\hline Cared for COVID patient & $599(38.5)$ & $69(11.5)$ & $1.10(0.79-1.54)$ & $396(34.8)$ & $29(7.3)$ & $0.85(0.52-1.34)$ & $203(48.4)$ & $40(19.7)$ & $1.13(0.67-1.92)$ \\
\hline $\begin{array}{l}\text { 3+ days in contact with COVID } \\
\text { patient }^{5}\end{array}$ & $263(43.9)$ & $35(13.3)$ & $1.39(0.83-2.33)$ & $158(39.9)$ & $19(12.0)$ & $2.84(1.27-6.69)$ & $105(51.7)$ & $16(15.2)$ & $0.61(0.29-1.24)$ \\
\hline $\begin{array}{l}\text { Participated in aerosol- } \\
\text { generating procedure }\end{array}$ & $160(26.7)$ & $15(9.4)$ & $0.70(0.37-1.27)$ & $116(29.3)$ & $6(5.2)$ & $0.51(0.18-1.27)$ & $44(21.7)$ & $9(20.5)$ & $1.10(0.44-2.55)$ \\
\hline
\end{tabular}

${ }^{1}$ Adjusted ORs and 95\% CI are adjusted for age, gender, race/ethnicity, known COVID exposure at home, role, location, and whether individual cared for COVID patient.

${ }^{2}$ Each role is compared to the entire HCW population, e.g., physicians vs. non-physicians.

${ }^{3}$ Individuals may select multiple locations, thus categories are not mutually exclusive. Each aOR corresponds to relative odds of being COVID AB-seropositive for individuals who worked in the specified location versus those who did not.

${ }^{4} \mathrm{HCWs}$ may report multiple exposures or symptoms. Each aOR corresponds to relative odds of being COVID AB-seropositive for individuals who reported versus did not report the specified exposure or symptom.

${ }^{5}$ Days in contact with COVID patient and participated in aerosol-generating procedure only applicable for HCWs who reported "yes" to caring for COVID patients. 
medRxiv preprint doi: https://doi.org/10.1101/2020.12.17.20248430; this version posted December 19, 2020. The copyright holder for this preprint (which was not certified by peer review) is the author/funder, who has granted medRxiv a license to display the preprint in perpetuity.

It is made available under a CC-BY-NC 4.0 International license .

Table 3. Associations between HCW self-reported symptoms and SARS-CoV-2 seropositivity (AB prevalence) of HCW study population and subgroups segregated by prior rt-PCR testing.

\begin{tabular}{|c|c|c|c|c|c|c|c|c|c|}
\hline \multirow[b]{2}{*}{ Variable } & \multicolumn{3}{|c|}{ All HCWs ( $\mathrm{n}=1,557)$} & \multicolumn{3}{|c|}{ Not tested by rt-PCR $(\mathrm{n}=1,138)$} & \multicolumn{3}{|c|}{ Tested by rt-PCR $(\mathrm{n}=419)$} \\
\hline & HCWs, n (\%) & $\begin{array}{l}\text { COVID-19 AB } \\
\text { prevalence, } \\
\text { n (\%) }\end{array}$ & $\begin{array}{c}\text { Adjusted OR } \\
(95 \% \mathrm{CI})^{1}\end{array}$ & $\begin{array}{l}\text { HCWs, n } \\
(\%)\end{array}$ & $\begin{array}{l}\text { COVID-19 AB } \\
\text { prevalence, } \\
\text { n (\%) }\end{array}$ & $\begin{array}{c}\text { Adjusted OR } \\
(95 \% \mathrm{CI})^{1}\end{array}$ & $\begin{array}{l}\mathrm{HCWs}, \mathrm{n} \\
(\%)\end{array}$ & $\begin{array}{c}\text { COVID-19 AB } \\
\text { prevalence, } \\
\text { n (\%) }\end{array}$ & $\begin{array}{c}\text { Adjusted OR } \\
(95 \% \mathrm{CI})^{1}\end{array}$ \\
\hline Total & $1557(100)$ & $165(10.6)$ & & $1138(100)$ & $91(8.0)$ & & $419(100)$ & $74(17.7)$ & \\
\hline Symptoms $^{2}$ & & & & & & & & & \\
\hline Sore throat & $633(40.7)$ & $79(12.5)$ & $1.38(1.00-1.92)$ & $405(35.6)$ & $41(10.1)$ & $1.47(0.95-2.27)$ & $228(54.4)$ & $38(16.7)$ & $0.95(0.56-1.60)$ \\
\hline Fatigue & $429(27.6)$ & $63(14.7)$ & $1.77(1.25-2.49)$ & $244(21.4)$ & $17(7.0)$ & $0.79(0.44-1.35)$ & $185(44.2)$ & $46(24.9)$ & $2.94(1.72-5.12)$ \\
\hline Muscle aches & $361(23.2)$ & $55(15.2)$ & $1.76(1.23-2.50)$ & $198(17.4)$ & $15(7.6)$ & $0.89(0.48-1.56)$ & $163(38.9)$ & $40(24.5)$ & $2.20(1.30-3.74)$ \\
\hline New cough & $470(30.2)$ & $54(11.5)$ & $1.11(0.78-1.57)$ & $292(25.7)$ & $18(6.2)$ & $0.65(0.36-1.09)$ & $178(42.5)$ & $36(20.2)$ & $1.50(0.89-2.53)$ \\
\hline New chills & $327(21.0)$ & $51(15.6)$ & $1.79(1.24-2.55)$ & $183(16.1)$ & $12(6.6)$ & $0.74(0.37-1.34)$ & $144(34.4)$ & $39(27.1)$ & $2.61(1.55-4.44)$ \\
\hline Fever & $318(20.4)$ & $48(15.1)$ & $1.67(1.15-2.39)$ & $177(15.6)$ & $11(6.2)$ & $0.67(0.33-1.24)$ & $141(33.7)$ & $37(26.2)$ & $2.38(1.40-4.04)$ \\
\hline Anosmia & $95(6.1)$ & $33(34.7)$ & $5.34(3.33-8.45)$ & $40(3.5)$ & $5(12.5)$ & $1.67(0.56-4.08)$ & $55(13.1)$ & $28(50.9)$ & $7.67(4.05-14.76)$ \\
\hline Dyspnea & $200(12.8)$ & $27(13.5)$ & $1.38(0.87-2.13)$ & $113(9.9)$ & $8(7.1)$ & $0.83(0.36-1.68)$ & $87(20.8)$ & $19(21.8)$ & $1.61(0.86-2.91)$ \\
\hline
\end{tabular}

${ }^{1}$ Adjusted ORs and 95\% CI are adjusted for age, gender, race/ethnicity, known COVID exposure at home, role, location, and whether individual cared for COVID-19 patient.

${ }^{2}$ HCWs may report multiple exposures and/or symptoms. Each adjusted OR corresponds to relative odds of being COVID AB seropositive for individuals who reported versus did not report the specified exposure or symptom. 
medRxiv preprint doi: https://doi.org/10.1101/2020.12.17.20248430; this version posted December 19, 2020. The copyright holder for this preprint (which was not certified by peer review) is the author/funder, who has granted medRxiv a license to display the preprint in perpetuity.

It is made available under a CC-BY-NC 4.0 International license.

\section{Figures}
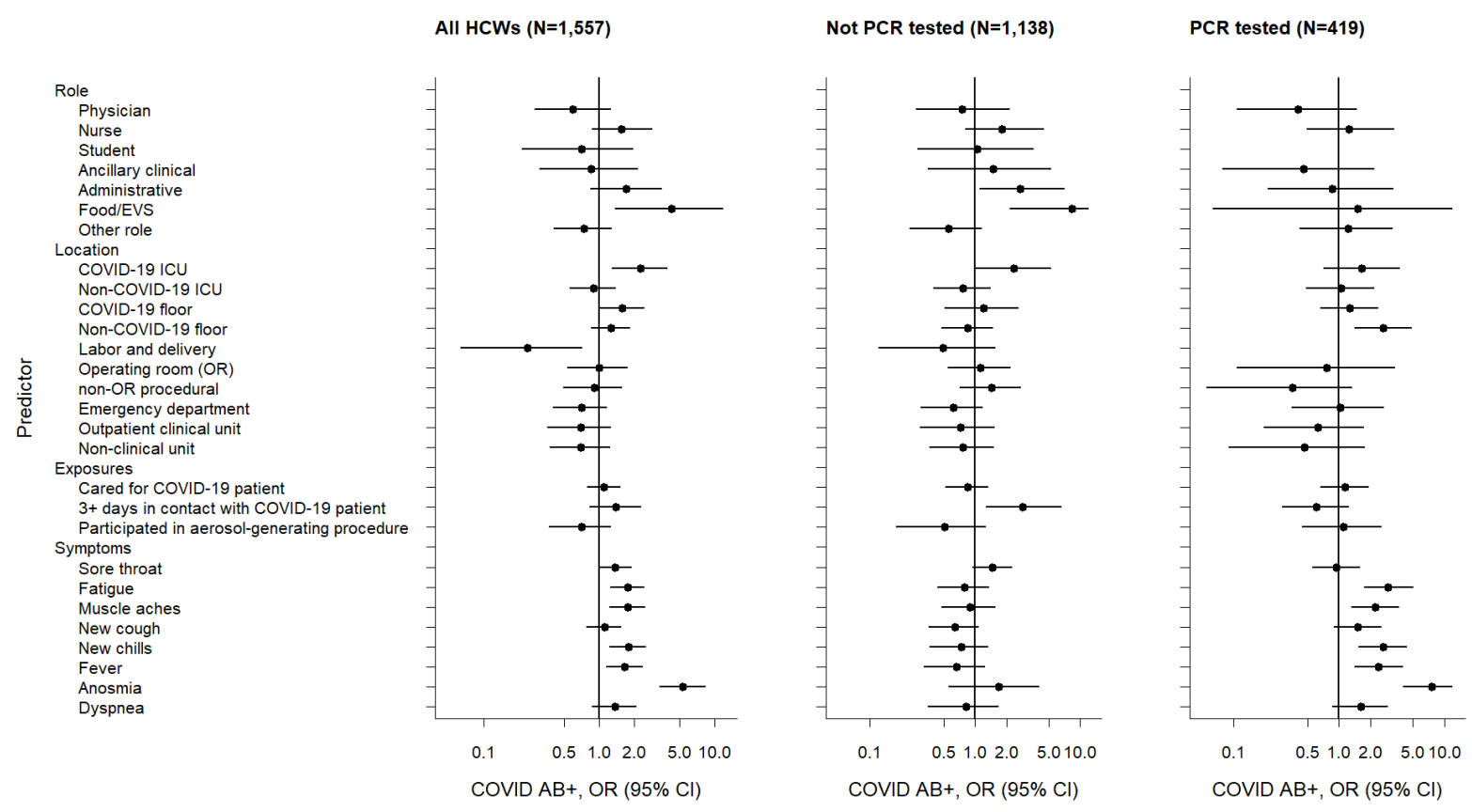

Figure 1. Forest plot of adjusted odds ratios (OR) of hypothesized predictors of COVID-19 seropositivity $(\mathrm{AB}+)$ among $\mathrm{HCW}$ study population and subgroups segregated by prior rt-PCR testing. ORs are adjusted for sex, age, race/ethnicity, known COVID-19 exposure outside of work, role, location, and COVID-19 patient contact. (EVS, environmental services) 
medRxiv preprint doi: https://doi.org/10.1101/2020.12.17.20248430; this version posted December 19, 2020. The copyright holder for this preprint (which was not certified by peer review) is the author/funder, who has granted medRxiv a license to display the preprint in perpetuity.

It is made available under a CC-BY-NC 4.0 International license .

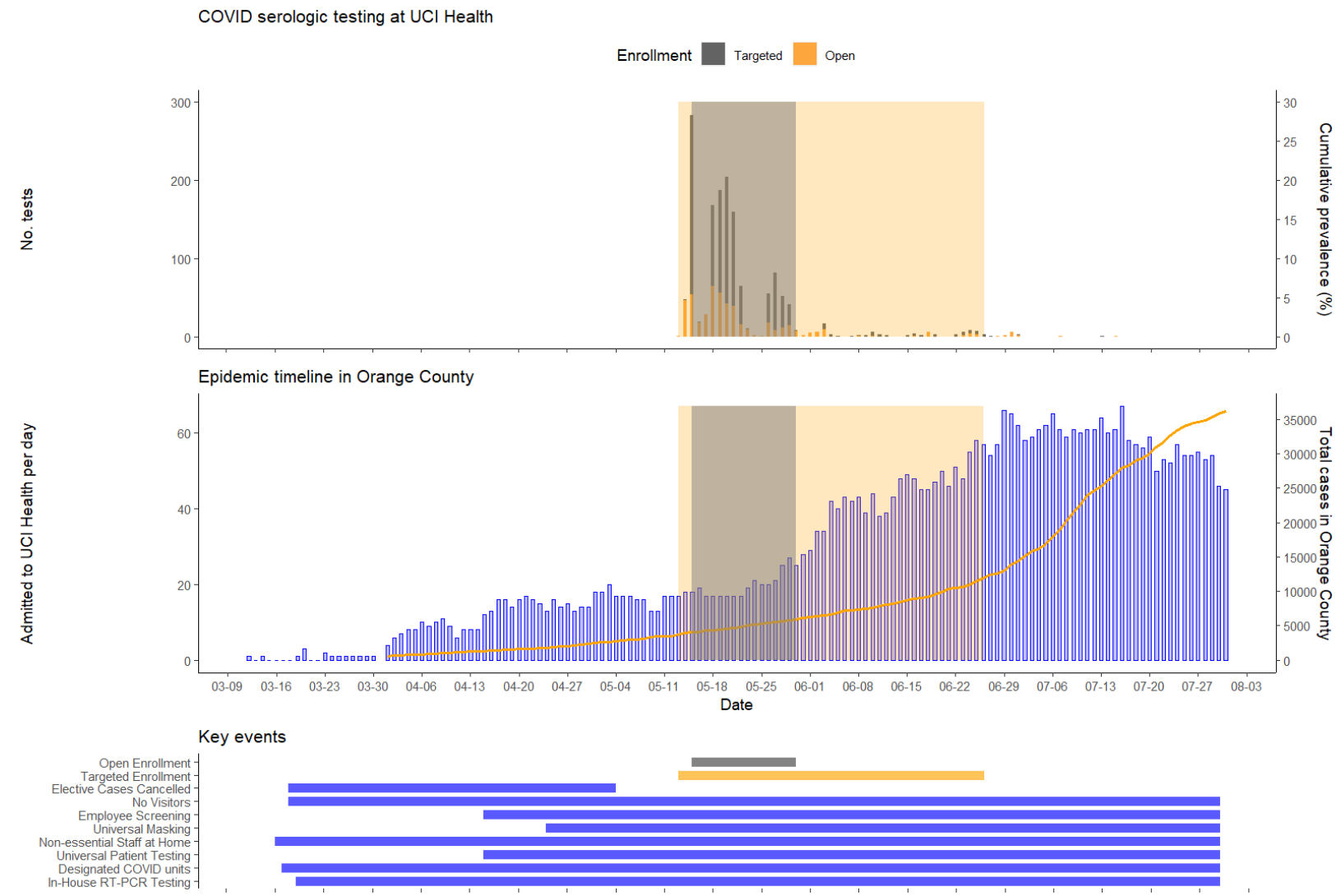

Figure 2. Epidemiologic context of HCW study with respect to community prevalence and hospital burden of COVID-19. 
medRxiv preprint doi: https://doi.org/10.1101/2020.12.17.20248430; this version posted December 19, 2020. The copyright holder for this preprint (which was not certified by peer review) is the author/funder, who has granted medRxiv a license to display the preprint in perpetuity.

It is made available under a CC-BY-NC 4.0 International license .

\section{Supplementary Information}

\section{Supplementary Tables}

Supplementary Table 1. Association between demographic and health-related characteristics and SARS-CoV-2 seropositivity (AB prevalence) of HCW study population and subgroups segregated by enrollment group. (COPD, chronic obstructive pulmonary disease)

\begin{tabular}{|c|c|c|c|c|c|c|c|c|c|}
\hline \multirow[b]{2}{*}{ Variable } & \multicolumn{3}{|c|}{ All HCWs $(\mathrm{n}=1,557)$} & \multicolumn{3}{|c|}{ Open enrollment $(\mathrm{n}=1,044)$} & \multicolumn{3}{|c|}{ Targeted enrollment $(\mathrm{n}=513)$} \\
\hline & $\begin{array}{l}\text { HCWs, n } \\
(\%)\end{array}$ & $\begin{array}{c}\text { COVID-19 } \\
\text { AB } \\
\text { prevalence, } \\
\text { n (\%) }\end{array}$ & OR $(95 \% \mathrm{CI})^{1}$ & $\begin{array}{l}\text { HCWs, n } \\
(\%)\end{array}$ & $\begin{array}{c}\text { COVID-19 } \\
\text { AB } \\
\text { prevalence, } \\
\text { n (\%) }\end{array}$ & OR $(95 \% \mathrm{Cl})^{1}$ & $\begin{array}{l}\text { HCWs, n } \\
(\%)\end{array}$ & $\begin{array}{c}\text { COVID-19 } \\
\text { AB } \\
\text { prevalence, } \\
\text { n (\%) }\end{array}$ & OR $(95 \% \mathrm{Cl})^{1}$ \\
\hline Total & $1557(100.0)$ & $165(10.6)$ & & $\begin{array}{c}1044 \\
(100.0)\end{array}$ & $83(8.0)$ & & $\begin{array}{c}513 \\
(100.0)\end{array}$ & $82(16.0)$ & \\
\hline \multicolumn{10}{|l|}{ Age quartiles (y) } \\
\hline $18-31$ & $418(26.8)$ & $49(11.7)$ & $\begin{array}{l}1.17(0.82- \\
1.66)\end{array}$ & $268(25.7)$ & $23(8.6)$ & $\begin{array}{c}1.12(0.67- \\
1.83)\end{array}$ & $150(29.2)$ & $26(17.3)$ & $\begin{array}{l}1.15(0.68- \\
1.90)\end{array}$ \\
\hline $32-38$ & $382(24.5)$ & $41(10.7)$ & $\begin{array}{c}1.02(0.69- \\
1.47)\end{array}$ & $244(23.4)$ & $24(9.8)$ & $\begin{array}{c}1.37(0.82- \\
2.23)\end{array}$ & $138(26.9)$ & $17(12.3)$ & $\begin{array}{c}0.67(0.37- \\
1.17)\end{array}$ \\
\hline $39-43$ & $377(24.2)$ & $35(9.3)$ & $\begin{array}{c}0.83(0.55- \\
1.21)\end{array}$ & $258(24.7)$ & $15(5.8)$ & $\begin{array}{l}0.65(0.35- \\
1.13)\end{array}$ & $119(23.2)$ & $20(16.8)$ & $\begin{array}{c}1.08(0.61- \\
1.85)\end{array}$ \\
\hline $49-73$ & $380(24.4)$ & $40(10.5)$ & $\begin{array}{c}0.99(0.67- \\
1.43)\end{array}$ & $274(26.2)$ & $21(7.7)$ & $\begin{array}{c}0.95(0.55- \\
1.56)\end{array}$ & $106(20.7)$ & $19(17.9)$ & $\begin{array}{l}1.19(0.66- \\
2.06)\end{array}$ \\
\hline \multicolumn{10}{|l|}{ Gender } \\
\hline Female & $1073(68.9)$ & $100(9.3)$ & $\begin{array}{l}0.66(0.48- \\
0.93)\end{array}$ & $696(66.7)$ & $47(6.8)$ & $\begin{array}{c}0.63(0.40- \\
0.99)\end{array}$ & $377(73.5)$ & $53(14.1)$ & $\begin{array}{c}0.60(0.37- \\
1.01)\end{array}$ \\
\hline Male & $482(31.0)$ & $64(13.3)$ & $\begin{array}{l}1.48(1.05- \\
2.06)\end{array}$ & $347(33.2)$ & $35(10.1)$ & $\begin{array}{l}1.52(0.96- \\
2.39)\end{array}$ & $135(26.3)$ & $29(21.5)$ & $\begin{array}{l}1.68(1.01- \\
2.76)\end{array}$ \\
\hline Other ${ }^{2}$ & $2(0.1)$ & $1(50.0)$ & - & $1(0.1)$ & $1(100)$ & - & $1(0.1)$ & 0 & - \\
\hline \multicolumn{10}{|l|}{ Race/ethnicity } \\
\hline Asian & $608(39.0)$ & $70(11.5)$ & $\begin{array}{c}1.17(0.84- \\
1.62)\end{array}$ & $357(34.2)$ & $23(6.4)$ & $\begin{array}{l}0.72(0.43- \\
1.17)\end{array}$ & $251(48.9)$ & $47(18.7)$ & $\begin{array}{c}1.49(0.93- \\
2.42)\end{array}$ \\
\hline White & $457(29.4)$ & $46(10.1)$ & $\begin{array}{c}0.92(0.64- \\
1.31)\end{array}$ & $332(31.8)$ & $30(9.0)$ & $\begin{array}{c}1.24(0.77- \\
1.96)\end{array}$ & $125(24.4)$ & $16(12.8)$ & $\begin{array}{c}0.72(0.39- \\
1.26)\end{array}$ \\
\hline Latino & $286(18.4)$ & $27(9.4)$ & $\begin{array}{c}0.86(0.54- \\
1.30)\end{array}$ & $228(21.8)$ & $17(7.5)$ & $\begin{array}{c}0.92(0.51- \\
1.56)\end{array}$ & $58(11.3)$ & $10(17.2)$ & $\begin{array}{l}1.11(0.51- \\
2.21)\end{array}$ \\
\hline Black & $29(1.9)$ & $3(10.3)$ & $\begin{array}{c}0.97(0.23- \\
2.80)\end{array}$ & $23(2.2)$ & $2(8.7)$ & $\begin{array}{c}1.11(0.17- \\
3.86)\end{array}$ & $6(1.2)$ & $1(16.7)$ & $\begin{array}{c}1.05(0.05- \\
6.63)\end{array}$ \\
\hline $\begin{array}{l}\text { Mixed/Other/Not } \\
\text { reported }\end{array}$ & $177(11.4)$ & $19(10.7)$ & $\begin{array}{l}1.02(0.60- \\
1.65)\end{array}$ & $104(10.0)$ & $11(10.6)$ & $\begin{array}{c}1.43(0.69- \\
2.68)\end{array}$ & $73(14.2)$ & $8(11.0)$ & $\begin{array}{c}0.61(0.26- \\
1.25)\end{array}$ \\
\hline \multicolumn{10}{|l|}{ Comorbidities } \\
\hline Any comorbidities & $370(23.8)$ & $41(11.1)$ & $\begin{array}{l}1.07(0.73- \\
1.54)\end{array}$ & $243(23.3)$ & $20(8.2)$ & $\begin{array}{c}1.05(0.61- \\
1.75)\end{array}$ & $127(24.8)$ & $21(16.5)$ & $\begin{array}{c}1.06(0.60- \\
1.79)\end{array}$ \\
\hline Asthma or COPD & $155(10.0)$ & $16(10.3)$ & $\begin{array}{l}0.97(0.54- \\
1.62)\end{array}$ & $102(9.8)$ & $9(8.8)$ & $\begin{array}{c}1.14(0.52- \\
2.23)\end{array}$ & $53(10.3)$ & $7(13.2)$ & $\begin{array}{c}0.78(0.31- \\
1.69)\end{array}$ \\
\hline Diabetes mellitus & $67(4.3)$ & $10(14.9)$ & $\begin{array}{c}1.51(0.71- \\
2.89)\end{array}$ & $41(3.9)$ & $4(9.8)$ & $\begin{array}{c}1.26(0.37- \\
3.25)\end{array}$ & $26(5.1)$ & $6(23.1)$ & $\begin{array}{l}1.62(0.58- \\
3.95)\end{array}$ \\
\hline Hypertension & $172(11.0)$ & $18(10.5)$ & $\begin{array}{l}0.98(0.57- \\
1.61)\end{array}$ & $115(11.0)$ & $7(6.1)$ & $\begin{array}{c}0.73(0.30- \\
1.51)\end{array}$ & $57(11.1)$ & $11(19.3)$ & $\begin{array}{c}1.30(0.61- \\
2.54)\end{array}$ \\
\hline Smoking or vaping & $37(2.4)$ & $4(10.8)$ & $\begin{array}{l}1.02(0.30- \\
2.61)\end{array}$ & $23(2.2)$ & $1(4.3)$ & $\begin{array}{l}0.52(0.03- \\
2.53)\end{array}$ & $14(2.7)$ & $3(21.4)$ & $\begin{array}{c}1.45(0.32- \\
4.77)\end{array}$ \\
\hline $\begin{array}{l}\text { Known COVID-19 } \\
\text { exposure at home }\end{array}$ & $58(3.7)$ & $12(20.7)$ & $\begin{array}{l}2.29(1.14- \\
4.29)\end{array}$ & $33(3.2)$ & $6(18.2)$ & $\begin{array}{l}2.70(0.98- \\
6.32)\end{array}$ & $25(4.9)$ & $6(24.0)$ & $\begin{array}{c}1.71(0.61- \\
4.20)\end{array}$ \\
\hline
\end{tabular}

${ }^{1}$ Odds ratios (OR) are unadjusted, comparing the selected group to the entire HCW population.

${ }^{2}$ OR for Other gender omitted due to small sample size. 
medRxiv preprint doi: https://doi.org/10.1101/2020.12.17.20248430; this version posted December 19, 2020. The copyright holder for this preprint (which was not certified by peer review) is the author/funder, who has granted medRxiv a license to display the preprint in perpetuity.

It is made available under a CC-BY-NC 4.0 International license .

Supplementary Table 2. Association between HCW occupational factors and SARS-CoV-2 seropositivity (AB prevalence) of HCW study population and subgroups segregated by enrollment group.

\begin{tabular}{|c|c|c|c|c|c|c|c|c|c|}
\hline \multirow[b]{2}{*}{ Variable } & \multicolumn{3}{|c|}{ All HCWs $(\mathrm{n}=1,557)$} & \multicolumn{3}{|c|}{ Open enrollment/fingerstick ( $\mathrm{n}=1044)$} & \multicolumn{3}{|c|}{ Targeted enrollment/EIP $(\mathrm{n}=513)$} \\
\hline & HCWs, n (\%) & $\begin{array}{l}\text { COVID-19 AB } \\
\text { prevalence, } \\
\mathrm{n}(\%)\end{array}$ & $\begin{array}{c}\text { Adjusted OR } \\
(95 \% \mathrm{CI})^{1}\end{array}$ & $\begin{array}{l}\text { HCWs, } \mathrm{n} \\
(\%)\end{array}$ & $\begin{array}{c}\text { COVID-19 } \\
\text { AB } \\
\text { prevalence, } \\
\mathrm{n}(\%) \\
\end{array}$ & $\begin{array}{c}\text { Adjusted OR } \\
(95 \% \mathrm{CI})^{1}\end{array}$ & $\begin{array}{l}\text { HCWs, n } \\
(\%)\end{array}$ & $\begin{array}{l}\text { COVID-19 AB } \\
\text { prevalence, } \\
\mathrm{n}(\%)\end{array}$ & $\begin{array}{l}\text { Adjusted OR } \\
(95 \% \mathrm{CI})^{1}\end{array}$ \\
\hline Total & $1557(100.0)$ & $165(10.6)$ & & $\begin{array}{c}1044 \\
(100.0)\end{array}$ & $83(8.0)$ & & $513(100.0)$ & $82(16.0)$ & \\
\hline \multicolumn{10}{|l|}{ Role $^{2}$} \\
\hline Physician & $246(15.8)$ & $17(6.9)$ & $0.59(0.28-1.27)$ & $170(16.3)$ & $11(6.5)$ & $0.74(0.28-1.96)$ & $76(14.8)$ & $6(7.9)$ & $0.26(0.06-1.04)$ \\
\hline Nurse & $705(45.3)$ & $90(12.8)$ & $1.55(0.87-2.91)$ & $370(35.4)$ & $32(8.6)$ & $1.44(0.66-3.39)$ & $335(65.3)$ & $58(17.3)$ & $1.22(0.48-3.49)$ \\
\hline Student & $69(4.4)$ & $5(7.2)$ & $0.70(0.21-1.98)$ & $69(6.6)$ & $5(7.2)$ & $0.77(0.21-2.52)$ & $0(0)$ & - & - \\
\hline Ancillary clinical staff & $88(5.7)$ & $7(8.0)$ & $0.85(0.30-2.18)$ & $60(5.7)$ & $3(5.0)$ & $0.84(0.17-3.20)$ & $28(5.5)$ & $4(14.3)$ & $0.90(0.19-3.75)$ \\
\hline Administrative & $205(13.2)$ & $23(11.2)$ & $1.71(0.84-3.52)$ & $171(16.4)$ & $15(8.8)$ & $1.71(0.71-4.25)$ & $34(6.6)$ & $8(23.5)$ & $1.57(0.44-5.66)$ \\
\hline Food / environmental & $46(3.0)$ & $7(15.2)$ & $4.26(1.37-12.61)$ & $46(4.4)$ & $7(15.2)$ & $6.30(1.84-21.39)$ & $0(0)$ & - & - \\
\hline Other & $199(12.8)$ & $16(8.0)$ & $0.70(0.39-1.18)$ & $158(15.1)$ & $10(6.3)$ & $0.72(0.34-1.38)$ & $41(8.0)$ & $6(14.6)$ & $0.93(0.34-2.18)$ \\
\hline \multicolumn{10}{|l|}{ Location $^{3}$} \\
\hline COVID-19 ICU & $171(11.0)$ & $26(15.2)$ & $2.28(1.29-3.96)$ & $98(9.4)$ & $9(9.2)$ & $2.49(0.89-6.39)$ & $73(14.2)$ & $17(23.3)$ & $2.07(0.95-4.48)$ \\
\hline Non-COVID-19 ICU & $364(23.4)$ & $38(10.4)$ & $0.89(0.56-1.39)$ & $254(24.3)$ & $17(6.7)$ & $0.74(0.36-1.40)$ & $110(21.4)$ & $21(19.1)$ & $1.25(0.62-2.47)$ \\
\hline COVID-19 floor & $261(16.8)$ & $35(13.4)$ & $1.59(1.01-2.48)$ & $131(12.5)$ & $10(7.6)$ & $1.25(0.49-2.94)$ & $130(25.3)$ & $25(19.2)$ & $1.68(0.91-3.08)$ \\
\hline Non-COVID-19 floor & $436(28.0)$ & $50(11.5)$ & $1.26(0.85-1.85)$ & $282(27.0)$ & $24(8.5)$ & $1.22(0.68-2.14)$ & $154(30.0)$ & $26(16.9)$ & $1.67(0.91-3.03)$ \\
\hline Labor and delivery & $113(7.3)$ & $4(3.5)$ & $0.24(0.06-0.72)$ & $102(9.8)$ & $4(3.9)$ & $0.35(0.08-1.13)$ & $11(2.1)$ & 0 & - \\
\hline Operating room & $196(12.6)$ & $15(7.7)$ & $0.99(0.53-1.78)$ & $183(17.5)$ & $13(7.1)$ & $1.00(0.48-1.93)$ & $13(2.5)$ & $2(15.4)$ & $3.34(0.43-18.11)$ \\
\hline $\begin{array}{l}\text { non-operating room } \\
\text { procedural }\end{array}$ & $198(12.7)$ & $16(8.1)$ & $0.91(0.49-1.59)$ & $180(17.2)$ & $14(7.8)$ & $1.10(0.54-2.09)$ & $18(3.5)$ & $2(11.1)$ & $0.75(0.10-3.25)$ \\
\hline Emergency department & $250(16.1)$ & $20(8.0)$ & $0.70(0.40-1.18)$ & $143(13.7)$ & $9(6.3)$ & $0.68(0.28-1.47)$ & $107(20.9)$ & $11(10.3)$ & $0.76(0.33-1.68)$ \\
\hline Outpatient clinical unit & $188(12.1)$ & $13(6.9)$ & $0.70(0.36-1.27)$ & $162(15.5)$ & $10(6.2)$ & $0.82(0.37-1.66)$ & $26(5.1)$ & $3(11.5)$ & $0.87(0.19-2.92)$ \\
\hline Non-clinical unit & $249(16.0)$ & $21(8.4)$ & $0.70(0.37-1.24)$ & $223(21.4)$ & $16(7.2)$ & $0.60(0.29-1.19)$ & $26(5.1)$ & $5(19.2)$ & $2.08(0.55-7.07)$ \\
\hline \multicolumn{10}{|l|}{ Job-related exposures ${ }^{2}$} \\
\hline $\begin{array}{l}\text { Cared for COVID-19 } \\
\text { patient }\end{array}$ & $599(38.5)$ & $69(11.5)$ & $1.10(0.79-1.54)$ & $305(29.2)$ & $21(6.9)$ & $0.74(0.43-1.24)$ & $294(57.3)$ & $48(16.3)$ & $1.02(0.63-1.69)$ \\
\hline $\begin{array}{l}\text { 3+ days in contact with } \\
\text { COVID-19 patient }{ }^{3}\end{array}$ & $263(43.9)$ & $35(13.3)$ & $1.39(0.83-2.33)$ & $121(39.7)$ & $7(5.8)$ & $0.70(0.25-1.78)$ & $142(48.3)$ & $28(19.7)$ & $1.74(0.92-3.36)$ \\
\hline $\begin{array}{l}\text { Participated in aerosol- } \\
\text { generating } \\
\text { procedure }^{3}\end{array}$ & $160(26.7)$ & $15(9.4)$ & $0.70(0.37-1.27)$ & $84(27.5)$ & $5(6.0)$ & $0.70(0.22-1.96)$ & $76(25.9)$ & $10(13.2)$ & $0.69(0.30-1.46)$ \\
\hline
\end{tabular}

${ }^{1}$ Adjusted ORs and 95\% CI are adjusted for age, gender, race/ethnicity, known COVID-19 exposure at home, role, location and whether an individual cared for a COVID-19 patient. ${ }^{2}$ Each role is compared to the entire HCW population, e.g., physicians vs. all non-physicians. ${ }^{3}$ Individuals may have selected multiple locations, thus categories are not mutually exclusive. 
medRxiv preprint doi: https://doi.org/10.1101/2020.12.17.20248430; this version posted December 19, 2020. The copyright holder for this preprint (which was not certified by peer review) is the author/funder, who has granted medRxiv a license to display the preprint in perpetuity.

It is made available under a CC-BY-NC 4.0 International license .

Supplementary Table 3. Association between HCW self-reported symptoms and SARS-CoV-2 seropositivity (AB prevalence) of HCW study population and subgroups segregated by enrollment group.

\begin{tabular}{|c|c|c|c|c|c|c|c|c|c|}
\hline Variable & HCWs, n (\%) & $\begin{array}{c}\text { All HCWs (n= } \\
\text { COVID-19 } \\
\text { AB } \\
\text { prevalence, } \\
\mathrm{n}(\%) \\
\end{array}$ & $\begin{array}{l}\text {,557) } \\
\text { Adjusted OR }(95 \% \\
\text { CI })^{1}\end{array}$ & HCWs, n (\%) & $\begin{array}{l}\text { COVID-19 AB } \\
\text { prevalence, } \\
\mathrm{n}(\%)\end{array}$ & $\begin{array}{l}1,044) \\
\text { Adjusted OR }(95 \% \\
\text { CI })^{1}\end{array}$ & HCWs, n (\%) & $\begin{array}{l}\text { COVID-19 AB } \\
\text { prevalence, } \\
\mathrm{n}(\%)\end{array}$ & $\begin{array}{l}\text { Adjusted OR }(95 \% \\
\text { CI })^{1}\end{array}$ \\
\hline $\begin{array}{l}\text { Total } \\
\text { Symptoms }\end{array}$ & $1557(100.0)$ & $165(10.6)$ & & $1044(100.0)$ & $83(8.0)$ & & $513(100.0)$ & $82(16.0)$ & \\
\hline Sore throat & $633(40.7)$ & $79(12.5)$ & $1.38(1.00-1.92)$ & $415(39.8)$ & $35(8.4)$ & $1.07(0.67-1.70)$ & $218(42.5)$ & $44(20.2)$ & $1.72(1.06-2.79)$ \\
\hline Fatigue & $429(27.6)$ & $63(14.7)$ & $1.77(1.25-2.49)$ & $259(24.8)$ & $20(7.7)$ & $0.91(0.52-1.54)$ & $170(33.1)$ & $43(25.3)$ & $2.75(1.68-4.52)$ \\
\hline Muscle aches & $361(23.2)$ & $55(15.2)$ & $1.76(1.23-2.50)$ & $216(20.7)$ & $15(6.9)$ & $0.77(0.41-1.35)$ & $145(28.3)$ & $40(27.6)$ & $2.95(1.79-4.88)$ \\
\hline New cough & $470(30.2)$ & $54(11.5)$ & $1.11(0.78-1.57)$ & $305(29.2)$ & $22(7.2)$ & $0.81(0.47-1.33)$ & $165(32.2)$ & $32(19.4)$ & $1.41(0.85-2.31)$ \\
\hline New chills & $327(21.0)$ & $51(15.6)$ & $1.79(1.24-2.55)$ & $203(19.4)$ & $17(8.4)$ & $0.99(0.54-1.70)$ & $124(24.2)$ & $34(27.4)$ & $2.59(1.55-4.29)$ \\
\hline Fever & $318(20.4)$ & $48(15.1)$ & $1.67(1.15-2.39)$ & $191(18.3)$ & $15(7.9)$ & $0.90(0.48-1.59)$ & $127(24.8)$ & $33(26.0)$ & $2.34(1.40-3.86)$ \\
\hline Loss of smell & $95(6.1)$ & $33(34.7)$ & $5.34(3.33-8.45)$ & $51(4.9)$ & $9(17.6)$ & $2.47(1.07-5.12)$ & $44(8.6)$ & $24(54.5)$ & $8.50(4.37-16.75)$ \\
\hline Dyspnea & $200(12.8)$ & $27(13.5)$ & $1.38(0.87-2.13)$ & $131(12.5)$ & $12(9.2)$ & $1.11(0.54-2.08)$ & $69(13.5)$ & $15(21.7)$ & $1.49(0.77-2.77)$ \\
\hline
\end{tabular}

${ }^{1}$ Adjusted ORs and 95\% CI are adjusted for age, gender, race/ethnicity, known COVID-19 exposure at home, role, location and whether an individual cared for a COVID-19 patient.

${ }^{2}$ HCWs may have reported multiple exposures or symptoms. Each adjusted OR corresponds to relative odds of being COVID-19 AB-seropositive for individuals who reported versus did not report the specified exposure or symptom.

${ }^{3}$ Days in contact with a COVID-19 patient and participated in aerosol-generating procedure only applicable for HCWs who reported "yes" to caring for COVID-19 patients 
medRxiv preprint doi: https://doi.org/10.1101/2020.12.17.20248430; this version posted December 19, 2020. The copyright holder for this preprint (which was not certified by peer review) is the author/funder, who has granted medRxiv a license to display the preprint in perpetuity.

It is made available under a CC-BY-NC 4.0 International license.

Supplementary Table 4. Demographic and health-related characteristics and SARS-CoV-2 seropositivity of HCW subgroups without prior rt-PCR testing and with prior positive and negative rt-PCR testing.

\begin{tabular}{|c|c|c|c|c|c|c|}
\hline \multirow[b]{2}{*}{ Variable } & \multicolumn{2}{|c|}{ Not tested for PCR } & \multicolumn{2}{|r|}{ PCR+ } & \multicolumn{2}{|r|}{ PCR- } \\
\hline & HCWs, n (\%) & COVID AB+, n (\%) & HCWs, n (\%) & COVID AB+, n (\%) & HCWs, n (\%) & COVID AB+, n (\%) \\
\hline \multirow{2}{*}{\multicolumn{7}{|c|}{$\begin{array}{l}\text { Total } \\
\text { Age quartiles (y) }\end{array}$}} \\
\hline & & & & & & \\
\hline $18-31$ & $311(27.3)$ & $33(10.6)$ & $7(18.4)$ & $6(85.7)$ & $86(26.7)$ & $7(8.1)$ \\
\hline $32-38$ & $257(22.6)$ & $22(8.6)$ & $9(23.7)$ & $8(88.9)$ & $98(30.4)$ & $10(10.2)$ \\
\hline $39-43$ & $275(24.2)$ & $15(5.5)$ & $11(28.9)$ & $11(100.0)$ & $74(23.0)$ & $7(9.5)$ \\
\hline $49-73$ & $295(25.9)$ & $21(7.1)$ & $11(28.9)$ & $11(100.0)$ & $64(19.9)$ & $6(9.4)$ \\
\hline \multicolumn{7}{|l|}{ Gender } \\
\hline Female & $781(68.6)$ & $57(7.3)$ & $22(57.9)$ & $21(95.5)$ & $228(70.8)$ & $18(7.9)$ \\
\hline Male & $355(31.2)$ & $33(9.3)$ & $16(42.1)$ & $15(93.8)$ & $94(29.2)$ & $12(12.8)$ \\
\hline \multicolumn{7}{|l|}{ Race/ethnicity } \\
\hline Asian & $415(36.5)$ & $26(6.3)$ & $23(60.5)$ & $22(95.7)$ & $151(46.9)$ & $19(12.6)$ \\
\hline White & $336(29.5)$ & $32(9.5)$ & $6(15.8)$ & $6(100.0)$ & $92(28.6)$ & $6(6.5)$ \\
\hline Latino & $232(20.4)$ & $18(7.8)$ & $7(18.4)$ & $7(100.0)$ & $45(14.0)$ & $1(2.2)$ \\
\hline Black & $25(2.2)$ & $2(8.0)$ & NA & NA & $3(0.9)$ & $1(33.3)$ \\
\hline Mixed/Other/Not reported & $130(11.4)$ & $13(10.0)$ & $2(5.3)$ & $1(50.0)$ & $31(9.6)$ & $3(9.7)$ \\
\hline \multicolumn{7}{|l|}{ Comorbidities } \\
\hline Any comorbidities & $258(22.7)$ & $18(7.0)$ & $14(36.8)$ & $14(100.0)$ & $80(24.8)$ & $7(8.8)$ \\
\hline Asthma or COPD & $114(10.0)$ & $9(7.9)$ & $3(7.9)$ & $3(100.0)$ & $31(9.6)$ & $2(6.5)$ \\
\hline Diabetes mellitus & $45(4.0)$ & $3(6.7)$ & $4(10.5)$ & $4(100.0)$ & $14(4.3)$ & $3(21.4)$ \\
\hline Hypertension & $118(10.4)$ & $5(4.2)$ & $9(23.7)$ & $9(100.0)$ & $39(12.1)$ & $4(10.3)$ \\
\hline Smoking or vaping & $24(2.1)$ & $2(8.3)$ & $1(2.6)$ & $1(100.0)$ & $10(3.1)$ & $1(10.0)$ \\
\hline $\begin{array}{l}\text { Known COVID-19 exposure at } \\
\text { home }\end{array}$ & $28(2.5)$ & $5(17.9)$ & $5(13.2)$ & $5(100.0)$ & $24(7.5)$ & $2(8.3)$ \\
\hline
\end{tabular}




\section{Supplementary Figures}
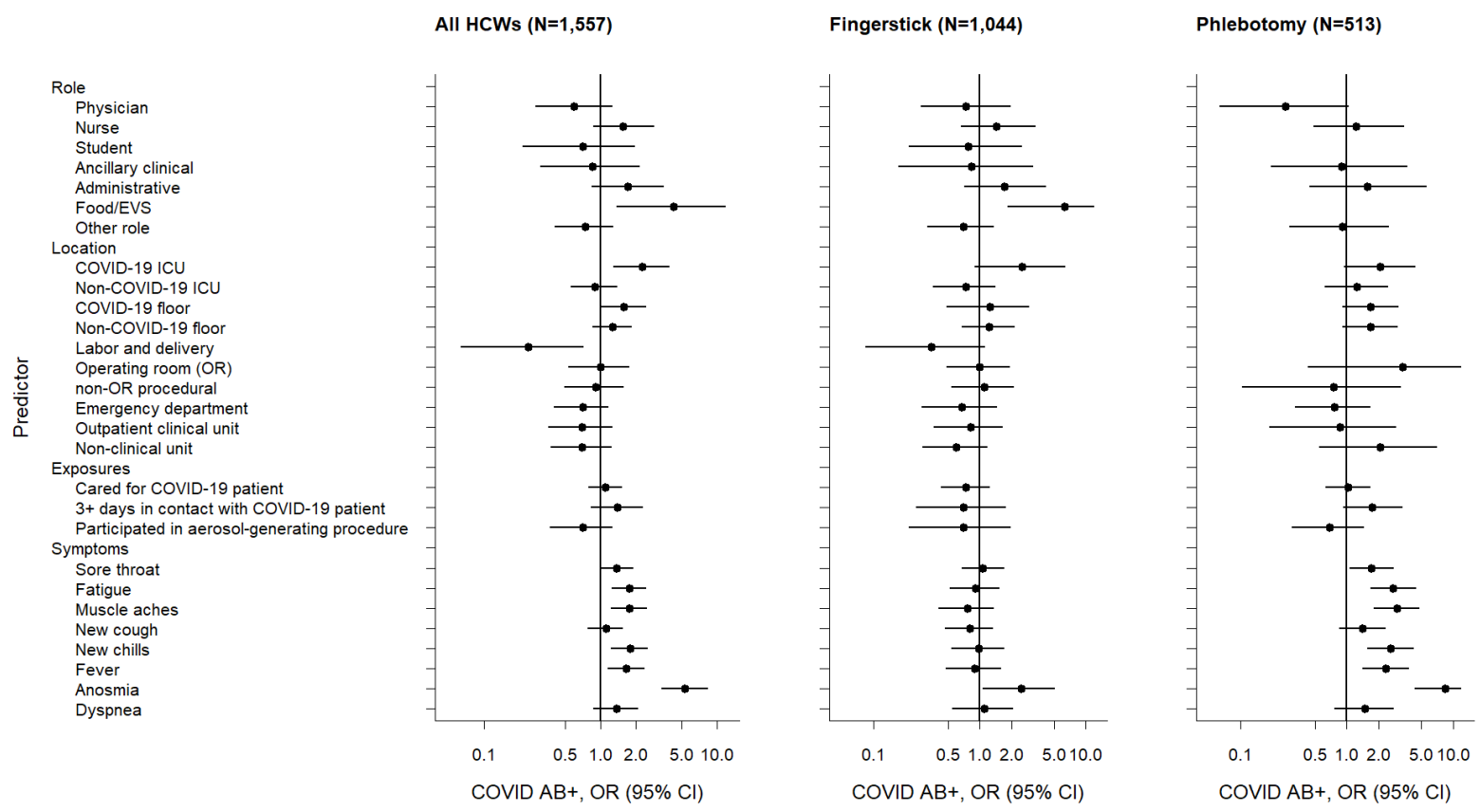

Supplementary Figure 1. Forest plot of adjusted odds ratios (OR) of hypothesized predictors of COVID-19 seropositivity (AB+) among HCW study population and subgroups segregated by enrollment group and sample collection method (Fingerstick = open enrollment cohort; Phlebotomy $=$ targeted enrollment cohort). ORs are adjusted for sex, age, race/ethnicity, known COVID-19 exposure outside of work, role, location, and COVID-19 patient contact. (EVS, environmental services) 
medRxiv preprint doi: https://doi.org/10.1101/2020.12.17.20248430; this version posted December 19, 2020. The copyright holder for this preprint (which was not certified by peer review) is the author/funder, who has granted medRxiv a license to display the preprint in perpetuity.

It is made available under a CC-BY-NC 4.0 International license .

\section{Appendices}

Appendix A. Survey utilized in this study. 


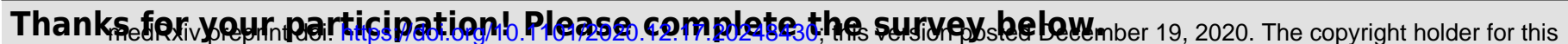
preprint (which was not certified by peer review) is the authorffunder, who has granted medRxiv a license to display the preprint in perpetuity. What is your first name (as listed in It is made available under a CC-BY-NC 4.0 International license.

What is your last name (as listed in HR)?

What is your role/title at $\mathrm{UCl}$ Health?

Administrative Staff

Admitting \& Registration/Billing

$\bigcirc$ Case Management/Social Worker

Dietary / Food Services

EIP

$\bigcirc$ Emergency Medical Technician

O EVS

IT Finance

Nurse

Nurse Aide

$\bigcirc$ Nutritionist

Occupational Therapist

$\bigcirc$ Pastoral Care

$\bigcirc$ Patient Experience

$\bigcirc$ Patient Safety \& Quality

$\bigcirc$ Pharmacist

Phlebotomist

Physical Therapist

Physician

$\bigcirc$ Researcher

$\bigcirc$ Respiratory Therapist

$\bigcirc$ Security

$\bigcirc$ Student

Telemetry, Radiology or Laboratory Technician

$\bigcirc$ Unit Secretary

$\bigcirc$ Other

What is your title?

Faculty

Resident

Fellow

Are you an ICU Nurse or non-ICU Nurse?

ICU Nurse non-ICU Nurse

Please provide your email address:

Please provide your badge number (5 digit serial number on ID card):

How long have you worked at $\mathrm{UCl}$ Health (estimated in years)? 


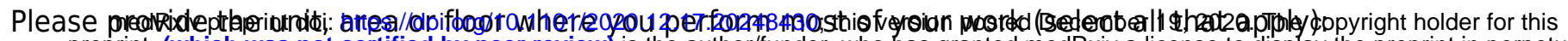
preprint (which was not certified by peer review) is the author/funder, who has granted medRxiv a license to display the preprint in perpetuity.

$\square$ Acute Rehabilitation Unit

Administration

Adolescent Partial Hospitalization Program

Adolescent Psychiatric Unit

Blood bank

Burn Intensive Care Unit (BICU)

Cardiac Catheterization

Cardiac Intensive Care Unit (CCU)

Cafeteria

Center for Digestive Diseases

Center for Perioperative Care (CPC)

Central Sterile Processing Unit

Clinical Laboratory

Dietary / Food Services

DH 32 (Orthopedics)

DH 46/48 (Mother/Baby Unit)

DH 56 (Neuroscience Step Down Unit)

DH 58 (Medical-Surgical: Neuro/Trauma)

DH 66/68 (Surgical Step Down Unit/Telemetry)

DH 76 (Oncology)

DH 78 (Telemetry)

Emergency Department (ED)

EVS

Infusion Center

Interventional Radiology

Medical Intensive Care Unit (MICU)

Medical Psychiatric Unit

Neonatal Intensive Care Unit (NICU)

Neuroscience Intensive Care Unit (NSCU)

Operating Room

Outpatient Surgical Services (OSS)

Post-Anesthesia Care Unit (PACU)

Pre- and Post-Operative Care Unit (PPCU)

Radiology (XR, CT, MRI)

Surgical Intensive Unit (SICU)

2 Tower (Antepartum)

2 Tower (Labor and Delivery)

3 Tower (Telemetry)

4 Tower (Medical)

5 Tower (Telemetry)

What is your age?

Gender

Female

Male

Other

Race/Ethnicity

$\square$ American Indian/Alaska Native

Asian

Black or African American

$\square$ Latino or Hispanic

$\square$ Native Hawaiian or Other Pacific Islander

$\square$ White

More Than One Race

Unknown / Not Reported 
Height medRxiv preprint doi: https://doi.org/10.1101/2020.12.17.20248430; this versiof' 'od'sted December 19, 2020. The copyright holder for this preprint (which was not certified by peer review) is the author/funder, who has qraqned medRxiv a license to display the preprint in perpetuity. It is made available under a CC-BY-NQ4. Al|2tërnational license .
4'3"
4'4"
$4^{\prime} 5^{\prime \prime}$
4'6"
4'7"
4'8"
4'9"
4'10"
4'11"
$5^{\prime} 0^{\prime \prime}$
5'1"
5'2"
5'3"
$5^{\prime} 4^{\prime \prime}$
5'5"
$5^{\prime} 6^{\prime \prime}$
5 $5^{\prime \prime \prime}$
5'8"
$5^{\prime} 9^{\prime \prime}$
5'10"
5'11"
6'0"
6'1"
6'2"
6'3"
6'4"
6'5"
6'6"
6'7"
6'8"
6'9"
6'10"
6'11"
7'0"
7'1"
7'2"
○'3"

Weight (lbs):

Do you have any underlying/chronic medical conditions

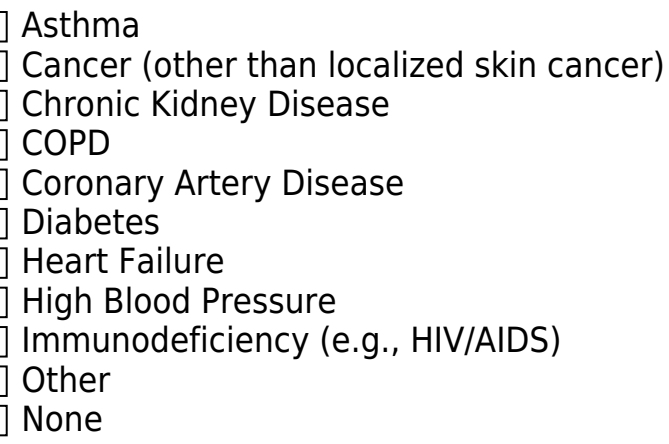

Do you smoke cigarettes? 


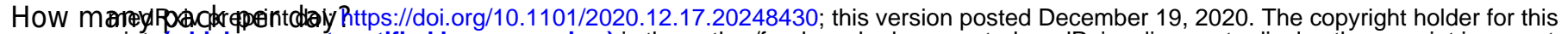
preprint (which was not certified by peer review) is the author/funder, who has granted medRxiv a license to display the preprint in perpetuity.

less than half a pack per day It is made available under a CC-BY-NC 4.0 International license .

0.5 packs per day

1 pack per day

1.5 packs per day

2 packs per day

more than 2 packs per day

$\begin{array}{ll}\text { Do you vape or use e-cigarettes? } & \bigcirc \text { Yes } \\ & \bigcirc \text { No }\end{array}$

How often do you vape?

a few times per week

$\bigcirc$ a few times a day

several times a day

regularly, throughout most of the day

$\begin{array}{ll}\text { Do you have an immunocompromising condition or } & \bigcirc \text { Yes } \\ \text { medication? } & \bigcirc \text { No }\end{array}$

If so, what is the condition or medication/s?

$\begin{array}{ll}\text { Have you cared for a known COVID+ patient? } & \bigcirc \text { Yes } \\ & \text { No }\end{array}$

How many days were you in contact with a known positive COVID patient?

Did you perform any aerosol-generating procedures on $\bigcirc$ Yes the patient?

No

Which of the following (select all that apply):

$\square$ bagging
$\square$ BiPAP
$\square$ bronchoscopy
$\square$ Code Blue/CPR
$\square$ disconnection of ventilator circuit
$\square$ intubation or extubation
$\square$ open suctioning
$\square$ other

Please specify the procedure:

Have you cared for any PUI/Suspected COVID+ patients?
$\bigcirc$ Yes
No
Maybe

How many days were you in contact with a PUI / suspected COVID+ patient?

Did you perform any aerosol-generating procedures on the PUI? 


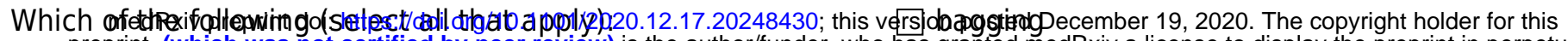
preprint (which was not certified by peer review) is the author/funder, who tap Bipstapl medRxiv a license to display the preprint in perpetuity.

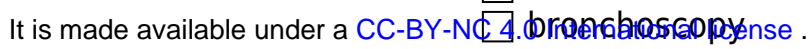
$\square$ Code Blue/CPR
$\square$ disconnection of ventilator circuit
$\square$ intubation or extubation
$\square$ open suctioning
$\square$ other

Please specify the procedure:
Do you have any known COVID+ community or home/family member contact?
Yes
No

If so, for how many days were you in contact with this person while they were symptomatic?
Have you been furloughed from work due to
$\bigcirc$ Yes suspected/known COVID+?
No

If so please provide the start date of the furlough:

$\begin{array}{ll}\text { Have you had any new fever anytime this calendar } & \bigcirc \text { Yes } \\ \text { year? } & \bigcirc \text { No }\end{array}$

If so when did the fever start?
1-7 days ago
8-14 days ago
14-30 days ago
1-2 months ago
2-3 months ago
$>3$ months ago

Please provide an approximate start date of this symptom

Did you measure your highest temperature?

Yes $\bigcirc$ No

Measurement (Fahrenheit)

$\begin{array}{ll}\text { Have you had any chills anytime this calendar year? } & \bigcirc \text { Yes } \\ & \text { No }\end{array}$

If so when did the chills start?
1-7 days ago
8-14 days ago
14-30 days ago
1-2 months ago
2-3 months ago
$\bigcirc>3$ months ago

Please provide an approximate start date of this symptom 


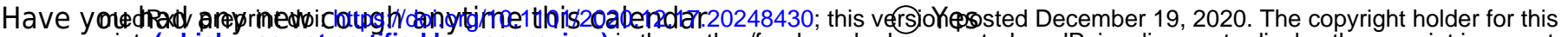
yeargreprint (which was not certified by peer review) is the author/funder, who has aronted medRxiv a license to display the preprint in perpetuity. It is made available under a CC-BY-NC 4.0 International license .

If so when did the cough start?

1-7 days ago

8-14 days ago

14-30 days ago

1-2 months ago

2-3 months ago

$\bigcirc>3$ months ago

Please provide an approximate start date of this symptom

Have you had difficulty breathing anytime this calendar year?
$\bigcirc$ Yes
No

If so when did the difficulty breathing start?
1-7 days ago
8-14 days ago
14-30 days ago
1-2 months ago
2-3 months ago
$\bigcirc>3$ months ago

Please provide an approximate start date of this symptom

Have you had any new runny nose, sinus congestion or sore throat anytime this calendar year?

$\bigcirc$ Yes
No

If so when did the runny nose, sinus congestion or sore throat start?
1-7 days ago
8-14 days ago
14-30 days ago
1-2 months ago
2-3 months ago
$0>3$ months ago

Please provide an approximate start date of any of these symptoms
Have you had a loss of smell or taste anytime this calendar year?
$\bigcirc$ Yes
No

If so when did the loss of smell or taste start?
1-7 days ago
8-14 days ago
14-30 days ago
1-2 months ago
2-3 months ago
$\bigcirc>3$ months ago

Please provide an approximate start date of any of these symptoms 


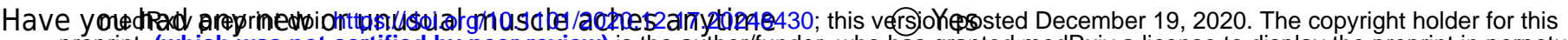
this erapeint dwhjegh mas not certified by peer review) is the author/funder, who has aranted medRxiv a license to display the preprint in perpetuity. It is made available under a CC-BY-NC 4.0 International license.

If so when did the new or unusual muscle aches start?

1-7 days ago

8-14 days ago

14-30 days ago

1-2 months ago

2-3 months ago

$0>3$ months ago

Please provide an approximate start date of this symptom
Have you had any new fatigue or tiredness anytime
Yes
this calendar year?
No

If so when did the new fatigue or tiredness start?
1-7 days ago
8-14 days ago
14-30 days ago
1-2 months ago
2-3 months ago
$\bigcirc>3$ months ago

Please provide an approximate start date of this symptom

Have you ever been tested for COVID-19?

$\bigcirc$ Yes

No

If so when were you tested?

What was your result?
Positive
$\bigcirc$ Negative
Pending

Were you told by your doctor that you could have COVID-19 but that testing was unavailable or not needed?

$\bigcirc$ Yes
No
Where you hospitalized for COVID?
Yes
No

If so, on what date:

Were you treated with oxygen?

Yes

No

For how many days? 


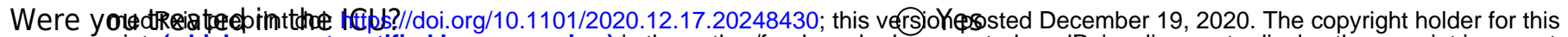
preprint (which was not certified by peer review) is the author/funder, who has $\mathbb{A}$ (3nted medRxiv a license to display the preprint in perpetuity.

It is made available under a CC-BY-NC 4.0 International license.

For how many days?

Were you on a mechanical ventilator?

Yes

No

For how many days?

Did you receive any of the following medications?

$\square$ hydroxychloroquine
$\square$ remdesivir
$\square$ tocilizumab
$\square$ steroids
$\square$ lopinavir/ritonavir
$\square$ antibiotics
$\square$ none of the above

